\title{
Microbial ecology of coral-dominated reefs in the Federated States of Micronesia
}

\author{
Amy Apprill ${ }^{1, *}$, Henry Holm ${ }^{1,2}$, Alyson E. Santoro ${ }^{3}$, Cynthia Becker ${ }^{1,2}$, \\ Matthew Neave ${ }^{1,6}$, Konrad Hughen ${ }^{1}$, Angela Richards Donà ${ }^{4}$, Greta Aeby ${ }^{4}$, \\ Thierry Work ${ }^{5}$, Laura Weber ${ }^{1}$, Sean McNally ${ }^{1,7}$ \\ ${ }^{1}$ Marine Chemistry and Geochemistry Department, Woods Hole Oceanographic Institution, Woods Hole, MA 02543, USA \\ ${ }^{2}$ MIT-WHOI Joint Program in Oceanography/Applied Ocean Science \& Engineering, Cambridge, MA 02139, USA \\ ${ }^{3}$ Department of Ecology, Evolution and Marine Biology, University of California, Santa Barbara, CA 93106, USA \\ ${ }^{4}$ University of Hawaii, Honolulu, HI 96822, USA \\ ${ }^{5}$ National Wildlife Health Center, Honolulu Field Station, U.S. Geological Survey, Honolulu, HI 96850, USA \\ ${ }^{6}$ Present address: Australian Animal Health Laboratory, CSIRO, Geelong, VIC 3219, Australia \\ ${ }^{7}$ Present address: School for the Environment, University of Massachusetts Boston, Boston, MA 02125, USA
}

\begin{abstract}
Microorganisms are central to the functioning of coral reef ecosystems, but their dynamics are unstudied on most reefs. We examined the microbial ecology of shallow reefs within the Federated States of Micronesia. We surveyed 20 reefs surrounding 7 islands and atolls (Yap, Woleai, Olimarao, Kosrae, Kapingamarangi, Nukuoro, and Pohnpei), spanning $875053 \mathrm{~km}^{2}$. On the reefs, we found consistently higher coral coverage (mean $\pm \mathrm{SD}=36.9 \pm 22.2 \%$; $\max 77 \%$ ) compared to macroalgae coverage $(15.2 \pm 15.5 \%$; max $58 \%)$, and low abundances of fish. Reef waters had low inorganic nutrient concentrations and were dominated by Synechococcus, Prochlorococcus, and SAR11 bacteria. The richness of bacterial and archaeal communities was significantly related to interactions between island/atoll and depth. High coral coverage on reefs was linked to higher relative abundances of Flavobacteriaceae, Leisingera, Owenweeksia, Vibrio, and the OM27 clade, as well as other heterotrophic bacterial groups, consistent with communities residing in waters near corals and within coral mucus. Microbial community structure at reef depth was significantly correlated with geographic distance, suggesting that island biogeography influences reef microbial communities. Reefs at Kosrae Island, which hosted the highest coral abundance and diversity, were unique compared to other locations; seawater from Kosrae reefs had the lowest organic carbon (59.8-67.9 $\mu \mathrm{M})$, highest organic nitrogen $(4.5-5.3 \mu \mathrm{M})$, and harbored consistent microbial communities ( $>85 \%$ similar), which were dominated by heterotrophic cells. This study suggests that the reef-water microbial ecology on Micronesian reefs is influenced by the density and diversity of corals as well as other biogeographical features.
\end{abstract}

KEY WORDS: Coral reef $\cdot$ Microbiology $\cdot$ Micronesia $\cdot$ Oligotrophic $\cdot$ Cyanobacteria $\cdot$ SSU rRNA gene

\section{INTRODUCTION}

Tropical coral reefs are among the most biodiverse and economically important ecosystems in the ocean (Moberg \& Folke 1999, Hughes et al. 2017). Most tropical coral reefs occur in oligotrophic waters, and reef-associated microorganisms and their biogeo-

${ }^{*}$ Corresponding author: aapprill@whoi.edu chemical processes are thought central to maintaining the high biomass and diversity associated with coral reefs (Sorokin 1973a). Microorganisms engage in symbiotic relationships with reef organisms, including corals and sponges, by providing carbon, nitrogen, and other critical substrates to their hosts (Wilkinson \& Fay 1979, Wilkinson 1983, Muscatine restricted. Authors and original publication must be credited. 
1990). Additionally, picoplankton (planktonic bacteria and archaea) play central roles in coral reef ecosystems by fixing carbon, cycling dissolved nutrients and organic matter, and serving as prey for abundant corals, sponges, and other reef filter feeders (Sorokin 1973b, Ducklow 1990, Houlbrèque et al. 2004, McNally et al. 2017).

Advances in microbial taxonomic identification methods have uncovered a rich diversity of planktonic bacteria and archaea in reef waters and have provided new insights into coupling between the water column and reef benthos. Several studies have identified distinct microbial communities overlying reefs that can be related to the physical structure of the reef (Nelson et al. 2011) or biological composition of the reef benthos (Dinsdale et al. 2008, Kelly et al. 2014, Haas et al. 2016, Weber et al. 2019, 2020). As coral reefs transition from coral to macroalgal dominance, their microbial communities also change, shifting to communities characterized by increased heterotrophy, virulence, and prevalence of pathogens (Kelly et al. 2014, Haas et al. 2016). These changes have been attributed to differences in the amount and composition of neutral sugars released in exudates from corals and algae (Haas et al. 2013, Nelson et al. 2013, Cárdenas et al. 2018), thus suggesting a direct link between benthic reef organisms and reefwater microorganisms. Further, a multi-sampling effort of Great Barrier Reef waters showed associations between reef-water microbial communities and water temperature and state of eutrophication (Glasl et al. 2019). Other reef-water microbiology studies have provided evidence of relationships between microbial communities and reef biogeography, suggesting that neutral community assembly processes also contribute to microbial community composition (Jeffries et al. 2015, Salerno et al. 2016).

Due to climate change and other anthropogenic impacts, coral reefs are among the most globally threatened ecosystems on Earth (Pandolfi et al. 2003, Hughes et al. 2017, 2018). Despite the likely importance of reef-water microorganisms and biogeochemical connections to the benthos, there are limited field-based measurements of nutrient and microbial parameters on reefs. Much of this knowledge for the Pacific is centered on higher-nutrient reefs near zones of oceanic upwelling (Dinsdale et al. 2008, Kelly et al. 2014) as well as an embayment in Mo'orea (Nelson et al. 2011). Recent studies have investigated oligotrophic reefs within a larger geographic area, thus providing additional context for understanding reefwater microbial ecology (Jeffries et al. 2015, Haas et al. 2016, Salerno et al. 2016, Weber et al. 2020).
The reefs comprising the Federated States of Micronesia (hereafter referred to as Micronesia) constitute one of the largest reef systems in the world. They are not located near nutrient upwelling zones, and their microbial biogeochemistry has not been previously investigated. Micronesia is composed of 4 states (Yap, Chuuk, Pohnpei, and Kosrae), consists of 607 islands, and houses over $14000 \mathrm{~km}^{2}$ of coral reefs, which surround a variety of islands and atolls covering $3000000 \mathrm{~km}^{2}$ of the North Pacific (Andrefouet et al. 2006). Island residents utilize the natural resources of these reefs for food, their livelihood, and traditional cultural practices. While storms (typhoons in 1990 in Pohnpei and 2004 in Chuuk and Yap) and coral bleaching $(1998,2004,2013-2017)$ have caused some mortality on reefs, these reefs are further threatened by human population growth, overharvesting, and habitat destruction (Abraham et al. 2004, Goldberg et al. 2008).

The purpose of this study was to examine the microbial ecology of coral reefs within the islands and atolls of Micronesia, in relation to benthic cover, select fish densities, biogeography, and the environmental conditions on the reefs. Over a 3 wk period in 2012, we examined 20 coral reefs spanning across 7 islands and atolls within Micronesia, with specific reefs opportunistically sampled alongside other unrelated cruise objectives. We hypothesized that the microbial ecology in the seawater overlying the reefs would vary according to the benthic composition of the reef as well as biogeographic features. By conducting reef surveys and water collections at these reefs, we found that most of the reefs harbored similar microbial communities, including an abundance of picocyanobacteria and oligotrophic-dwelling microbial taxa. Biogeographical distance-related differences as well as select nutrients also played a role in structuring differences within the reef seawater microbial communities. Lastly, we found that microbial diversity was positively correlated with coral coverage and that the reefs of Kosrae Island harbored high coral cover and high coral diversity, and displayed unique microbial biogeochemical properties, suggesting a link between the coral communities and pelagic reef-water microbial functioning.

\section{MATERIALS AND METHODS}

\subsection{Cruise overview and sites}

During 21 October to 10 November 2012, we studied 20 coral reefs spread over 7 islands and atolls in 
Micronesia with varying human populations (from uninhabited to 32178 residents). Two to 6 reef sites were examined per island or atoll (Fig. 1, Table 1; see Table S1 in the Supplement at www.int-res.com/ articles/suppl/a086p115_supp.xlsx), and geographic distances between sites spanned from 0.15 (intraisland/atoll) to $2775 \mathrm{~km}$ (between islands/atolls), covering an area of $875053 \mathrm{~km}^{2}$. The reefs ranged in depth from 6 to $13 \mathrm{~m}$, and included forereef, fringing, and lagoon reef habitats (Table 1). At each site, benthic and fish surveys were conducted using SCUBA, physicochemical seawater properties were measured, and surface $(1 \mathrm{~m})$ and reef depth seawater (taken within $1 \mathrm{~m}$ of the benthos) were sampled for specific microbial and biogeochemical measurements. Additionally, a deep off-reef (4261 m depth) location was sampled at the surface (1 m depth) for physicochemical seawater properties as well as microbial abundances and community composition.

\subsection{Reef surveys}

Two $25 \mathrm{~m}$ tape measures were deployed along depth contours and run from an appropriate spot near the anchor point into the oncoming current. The second transect began approximately $3 \mathrm{~m}$ from the end of the first transect and continued in the same direction. Substrate characteristics were measured using the point-intercept method, whereby the substrate underlying the tape measure was classified and recorded at $50 \mathrm{~cm}$ intervals. On the island of Yap, only coral coverage was quantified. Corals within $50 \mathrm{~cm}$ on either side of the tape measure $(25 \times 1 \mathrm{~m}$ belt) were examined, and all coral taxa, down to genus level, were recorded.

We surveyed herbivorous and corallivorous fish populations at each site. Standard underwater visual surveys of herbivorous species (parrotfish, surgeonfish, and rabbitfish) and coral-feeding species (butterflyfish) were conducted along the same belt transects as surveyed for coral abundance. A diver swam along each transect at a constant speed ( 15 min per transect), recording fish visible within $2-3 \mathrm{~m}$ to either side of the central line. Transect width (4 or $6 \mathrm{~m}$ ) was dependent on water clarity.

\subsection{Seawater physicochemical analysis and water sample collections}

Physicochemical properties of the seawater, including temperature, salinity, and dissolved oxygen, were measured at the sites using casts with an EXO water quality sonde (YSI). Cast data were averaged at surface and reef depths over $0.5 \mathrm{~m}$. Seawater samples were collected from surface and reef depths at each site, except for Yap, where only 1 sample of surface seawater was collected. Samples were collected for the following analyses: total organic carbon and nitrogen concentrations $(60 \mathrm{ml})$, inorganic nutrient concentrations $(100 \mathrm{ml})$, cell abundances $(1 \mathrm{ml})$, and microbial biomass for molecular analyses (4 l). Seawater for analysis of phytoplankton pigments (4 1) was only collected from surface waters. Surface samples were obtained by holding bottles under the water, and reef depth samples were collected using Niskin bottle casts. All samples were collected into triple-rinsed vials and stored on ice for up to $4 \mathrm{~h}$ before processing.

\subsection{Organic and inorganic nutrients, phytoplankton pigments, and cell abundances}

Seawater collected for inorganic nutrient analyses was frozen at $-20^{\circ} \mathrm{C}$, and concentrations of dissolved inorganic nutrients (ammonium, nitrate + nitrite, nitrite, phosphate, and silicate) were measured using a continuous segmented flow system including a Technicon AutoAnalyzer II (SEAL Analytical) and an Alpkem RFA 300 Rapid Flow Analyzer at Oregon State University. Nitrate + nitrite and nitrite were measured according to Armstrong et al. (1967), with detection limits of 0.07 and $0.01 \mu \mathrm{M}$, respectively. Phosphate was measured using an adjusted molybdenum blue method (Bernhardt \& Wilhelms 1967), with a detection limit of $0.01 \mu \mathrm{M}$. The majority (23 out of 34 total measurements) of ammonium measurements were conducted in the field on unfrozen samples using the ortho-phthaldialdehyde fluorescence method (Holmes et al. 1999, Taylor et al. 2007), with a detection limit of $0.02 \mu \mathrm{M}$ (Table S1). Autoanalyzer measurements were used to measure ammonium for the remaining (11/34) samples using the indophenol blue method (US Environmental Protection Agency 1983), with a detection limit of $0.02 \mu \mathrm{M}$. Seawater samples collected for total organic carbon (TOC) and total organic nitrogen (TON) analyses were acidified with phosphoric acid and stored at $4^{\circ} \mathrm{C}$ until analysis using a Shimadzu TOC- $\mathrm{V}_{\mathrm{CSH}}$ TOC analyzer (Hansell \& Carlson 2001), where total nonpurgeable particulate and dissolved organic carbon (TOC) and total particulate and dissolved inorganic and organic nitrogen (total nitrogen, TN) were resolved. TON concentrations were calculated by subtracting nitrate + nitrite and ammonium concentrations from TN concentrations. For analysis of 

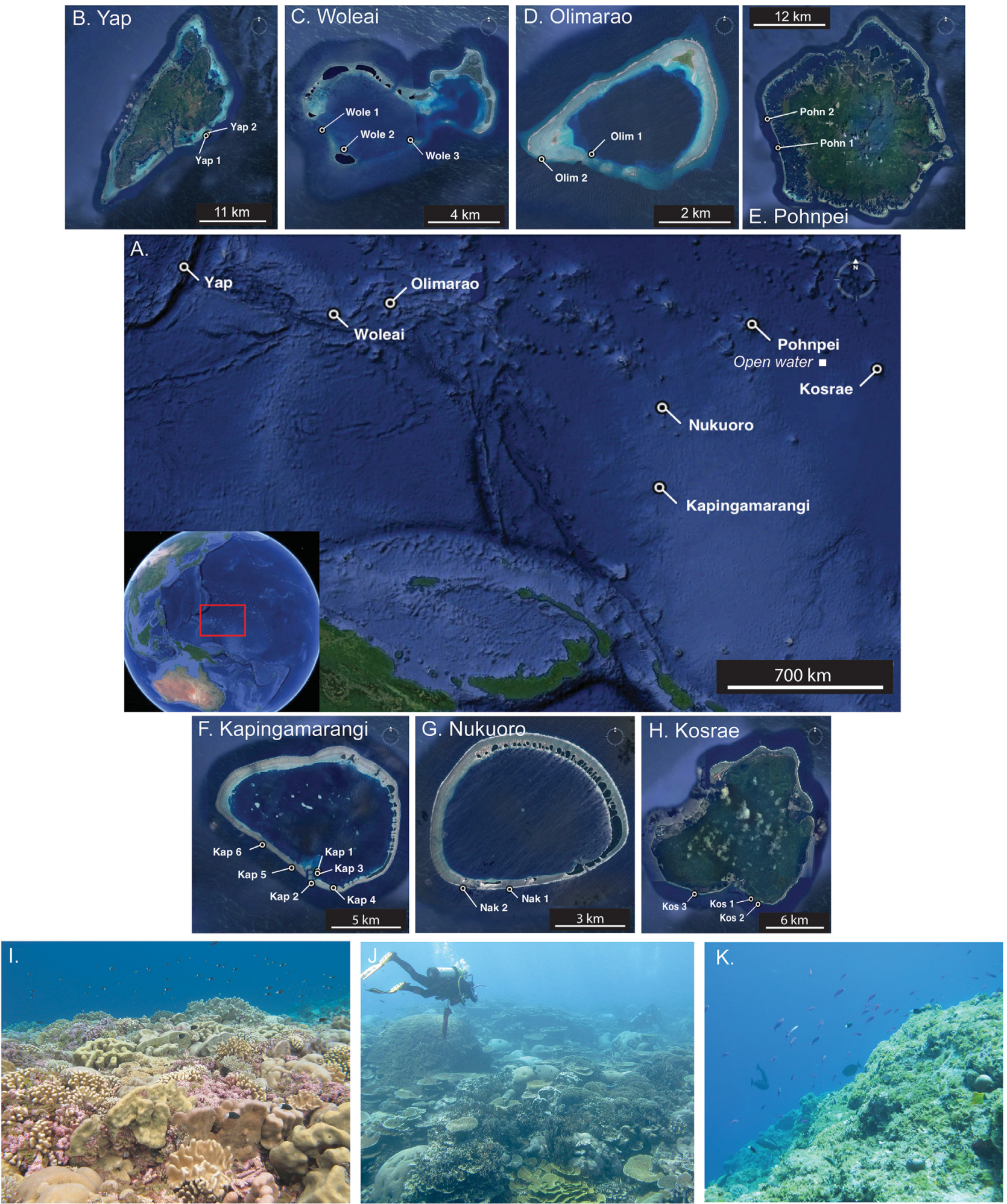

Fig. 1. Study sites in Micronesia. (A) Overview of the islands; inset displays the global location. Close-ups of field sites at each island or atoll: (B) Yap, (C) Woleai, (D) Olimarao, (E) Pohnpei, (F) Kapingamarangi, (G) Nukuoro, and (H) Kosrae. Representative photographs of coral reefs from highly coral-dominated (I) Nukuoro atoll and (J) Kosrae Island, and from (K) the macroalgal-dominated reef of Olimarao. Map images courtesy of Google Earth (2016) under the academic print distribution guidelines, including data from SIO, NOAA, US Navy, NGA, and GEBCO and images from the US Geological Survey, Cnes/Spot Image, and 2001 DigitalGlobe 
Table 1. Reef sites examined in this study. NA: not applicable

\begin{tabular}{|c|c|c|c|c|c|c|}
\hline $\begin{array}{l}\text { Site } \\
\text { name }\end{array}$ & Location & $\begin{array}{c}\text { Human } \\
\text { population }^{\mathrm{a}}\end{array}$ & $\begin{array}{c}\text { Reef depth } \\
\text { sampled }(\mathrm{m})^{\mathrm{b}}\end{array}$ & Reef type & $\begin{array}{l}\text { Latitude } \\
\left({ }^{\circ} \mathrm{N}\right)\end{array}$ & $\begin{array}{l}\text { Longitude } \\
\left({ }^{\circ} \mathrm{E}\right)\end{array}$ \\
\hline Yap 1 & Yap Island & 11241 & NA & Forereef & 9.507 & 138.175 \\
\hline Yap 2 & Yap Island & 11241 & NA & Forereef & 9.508 & 138.177 \\
\hline Wole 1 & Woleai Atoll & 978 & 10 & Forereef & 7.339 & 143.830 \\
\hline Wole 2 & Woleai Atoll & 978 & 6 & Lagoon & 7.330 & 143.840 \\
\hline Wole 3 & Woleai Atoll & 978 & 6 & Forereef & 7.334 & 143.872 \\
\hline Olim 1 & Olimarao Atoll & None & 6 & Forereef & 7.682 & 145.860 \\
\hline Olim 2 & Olimarao Atoll & None & 10 & Forereef & 7.681 & 145.850 \\
\hline Kos 1 & Kosrae Island & 7686 & 13 & Fringing & 5.263 & 162.984 \\
\hline Kos 2 & Kosrae Island & 7686 & 10 & Fringing & 5.259 & 162.990 \\
\hline Kos 3 & Kosrae Island & 7686 & 10 & Fringing & 5.266 & 162.935 \\
\hline Open water & NA & NA & NA & Offshore & 6.158 & 160.567 \\
\hline Kap 1 & Kapingamarangi Atoll & 474 & 8 & Lagoon & 1.037 & 154.766 \\
\hline Kap 2 & Kapingamarangi Atoll & 474 & 10 & Forereef & 1.029 & 154.762 \\
\hline Kap 3 & Kapingamarangi Atoll & 474 & 12 & Lagoon & 1.035 & 154.766 \\
\hline Kap 4 & Kapingamarangi Atoll & 474 & NA & Lagoon & 1.027 & 154.775 \\
\hline Kap 5 & Kapingamarangi Atoll & 474 & 12 & Forereef & 1.038 & 154.751 \\
\hline Kap 6 & Kapingamarangi Atoll & 474 & 10 & Forereef & 1.051 & 154.734 \\
\hline Nuk 1 & Nukuoro Atoll & 362 & 10 & Forereef & 3.821 & 154.936 \\
\hline Nuk 2 & Nukuoro Atoll & 362 & 10 & Forereef & 3.821 & 154.920 \\
\hline Poh 1 & Pohnpei Island & 32178 & 6 & Fringing & 6.863 & 158.107 \\
\hline Poh 2 & Pohnpei Island & 32178 & 10 & Fringing & 6.905 & 158.090 \\
\hline
\end{tabular}

phytoplankton pigments, 41 of seawater were filtered onto GF/F filters (Whatman) and frozen in liquid nitrogen until pigment extraction. Further processing and analysis of phytoplankton pigments were conducted using high-performance liquid chromatography at the Horn Point Laboratory of the University of Maryland Center for Environmental Science. Seawater samples $(1 \mathrm{ml})$ collected in duplicate for microbial cell enumeration were preserved with paraformaldehyde (1\% final concentration), fixed for $20 \mathrm{~min}$ in the dark, and frozen in liquid nitrogen. Abundances of Synechococcus, Prochlorococcus, picoeukaryotes, and unpigmented cells (a proxy for heterotrophic bacteria and archaea) were enumerated using flow cytometry at the University of Hawaii, similar to a previous methodological description (Apprill \& Rappé 2011). Fluorescence spectra were transformed into cell abundances using FlowJo software (v. 6.4.7).

\subsection{Picoplankton diversity and community structure}

For molecular analysis of picoplankton communities, duplicate samples (2 1) of seawater were filtered onto $25 \mathrm{~mm}, 0.22 \mu \mathrm{m}$ Supor polyethersulfone membrane filters (Pall) using peristalsis. Microbial biomass samples were frozen in liquid nitrogen until analysis. Genomic DNA was extracted from the filters by first bead beating at maximum speed with a benchtop vortexer and 24-tub vortex adapter (10 min) with sucrose-EDTA lysis buffer (0.75 M sucrose, $20 \mathrm{mM}$ EDTA, $400 \mathrm{mM} \mathrm{NaCl}, 50 \mathrm{mM}$ Tris) and $100 \mu \mathrm{l}$ of $10 \%$ sodium dodecyl sulfate, followed by a Proteinase K digestion for $4 \mathrm{~h}$ at $55^{\circ} \mathrm{C}$, and then purification with the DNeasy kit purification (Qiagen) (Santoro et al. 2010). The hypervariable IV region of small subunit (SSU) ribosomal RNA genes from bacteria and archaea was amplified using PCR with 515F (5'-GTG CCA GCM GCC GCG GTA A-3') (Caporaso et al. 2011) and 806RB (5'-GGA CTA CNV GGG TWT CTA AT-3') (Apprill et al. 2015) primers. The forward primer did not include the modification shown to increase recovery of Thaumarchaea (Parada et al. 2016). The primers were each equipped with a unique $8 \mathrm{bp}$ barcode, $10 \mathrm{bp}$ pad, and $2 \mathrm{bp}$ link, and were designed after Kozich et al. (2013). Reactions (25 $\mu \mathrm{l})$ were conducted in triplicate, and included $1.25 \mathrm{U}$ of GoTaq Flexi DNA Polymerase (Promega), 5× colorless GoTaq Flexi Buffer, $2.5 \mathrm{mM} \mathrm{MgCl}_{2}, 200 \mu \mathrm{M}$ dNTP mix (Promega), $200 \mathrm{nM}$ of each barcoded primer, as well as 1 to $4 \mathrm{ng}$ of genomic template (generally $1 \mu \mathrm{l}$ ). For 
the reactions, an initial denaturation step was conducted at $95^{\circ} \mathrm{C}$ for $2 \mathrm{~min}$, followed by 27-38 cycles of $95^{\circ} \mathrm{C}$ for $20 \mathrm{~s}, 55^{\circ} \mathrm{C}$ for $15 \mathrm{~s}$, and $72^{\circ} \mathrm{C}$ for $5 \mathrm{~min}$, concluding with an extension step at $72^{\circ} \mathrm{C}$ for $10 \mathrm{~min}$ on a thermocycler (Bio-Rad Laboratories). Reaction products $(5 \mu \mathrm{l})$ were screened on a $1 \%$ agarose/tris-borateEDTA gel using the HyperLadder 50 bp DNA ladder (Bioline) to validate the size of the amplified product and general PCR performance. The number of PCR cycles varied by sample in order to produce similar minimal PCR product yields across samples, and this was evaluated by visualizing the agarose gel. Triplicate amplicons were pooled for each sample and purified using the QIAquick Purification Kit (Qiagen) and quantified using a Qubit 2.0 fluorometer with the dsDNA High Sensitivity Assay (Invitrogen). Amplicons were pooled into equimolar ratios and shipped to the University of Illinois W.M. Keck Center for Comparative and Functional Genomics, where they were sequenced using paired-end 250 bp MiSeq (Illumina). Control samples included sterile water (negative control) and a mock community sample (positive control) that was obtained through BEI Resources, NIAID, and NIH as part of the Human Microbiome Project: Genomic DNA from Microbial Mock Community B (even, low concentration), v5.1L, HM782D. Results from these controls were as expected and the data are not presented.

Sequence data were analyzed using mothur v.1.33.3 (Schloss et al. 2009) and included construction of contigs from paired ends, quality filtering, alignment to the SSU rRNA gene, and chimera detection using UCHIME (Edgar et al. 2011). Samples contained 514755382 quality sequences (mean 26389). Sequences were grouped using minimum entropy decomposition (MED), which allocated sequences into $496 \mathrm{MED}$ nodes (also referred to as MEDs; range of 267-441 MED nodes per sample) representing homogeneous operational taxonomic units based on Shannon entropy decomposition (Eren et al. 2015). Taxonomy was assigned to the sequences using the $k$-nearestneighbor consensus algorithm in mothur using the Silva database (v119) (Quast et al. 2013). Sequences were not rarefied, due to the relatively even nature of the dataset and challenges associated with this practice (McMurdie \& Holmes 2014, Weiss et al. 2017). Statistical comparisons of microbial community sequence data were conducted using Primer-E software (v. 7.0.9) using non-rarefied sequence data. In order to compare sequences from each sample, we transformed the MED counts into relative abundances, then performed a square-root transformation of the MED relative abundances, and finally, the data were compared using Bray-Curtis dissimilarity (Bray $\&$ Curtis 1957). The Bray-Curtis dissimilarity data were then compared using CLUSTER, or hierarchical cluster analysis, using the group average mode as well as non-metric multi-dimensional scaling (nMDS) analysis with 1000 iterations, with vectors overlaid using Pearson correlation analysis. Permutational multivariate ANOVAs (PERMANOVAs) (Anderson 2001) were conducted using group average clustering methods, and Monte Carlo corrections were applied. Permutational analysis of multivariate dispersions (PERMDISP) permutation tests (Anderson 2006) were used to assess if within-group dispersion was responsible for any observed differences, as these differences can influence PERMANOVA results (Anderson \& Walsh 2013). We used the Bio-Env + Stepwise (BEST) analysis (Clarke \& Warwick 2001) in Primer to examine relationships between environmental parameters, benthic cover, and fish abundances (all square-root transformed), and the microbial community composition, conducted using the Spearman rank correlations. The BEST analysis searches for high rank correlations between the compared data, and reports the correlation coefficient (rho) and significance (p) value. RELATE analysis, a nonparametric form of the Mantel test conducted using the Spearman rank correlation method (Clarke \& Warwick 2001), was used to examine relationships between microbial community composition and geographic distances between sites, and data are reported as the correlation coefficient (rho) and significance (p) value. Similarity and percentages routine (SIMPER) analysis (Clarke \& Warwick 2001) was used to calculate the contribution of each microbial MED node to the dissimilarity between the island and atolls. SIMPER analysis was conducted using the relative abundance-based microbial composition data, and data are reported as specific MEDs that contributed to similarity within the group.

To further investigate relationships between specific microbial taxa and reef composition, differential abundance of all MED nodes was tested using the $\mathrm{R}$ (v 3.6.2) package 'corncob' (v 0.1.0), which employed beta-binomial regression models and accounted for varying sequencing depth and within-sample correlations between taxa (Martin et al. 2020). Specifically, 3 tests were performed to understand how abundances of the MED nodes changed with (1) increasing percent coral cover, (2) increasing percent macroalgal cover, and (3) between Olimarao (low coral cover reefs) and Kosrae (high coral cover reefs). Only reef depth microbial communities were used in this differential abundance analysis. Models examining 
increasing coral or macroalgal cover examined data from all sites with benthic coverage data (16 sites: Kap 1, 2, 3, 5, and 6; Kos 1, 2, and 3; Nuk 1 and 2; Olim 1 and 2; Poh 1 and 2; Wole 1 and 3), and these data included 496 MED nodes. The model examining just Olimarao and Kosrae utilized data from 5 sites (Kos 1, 2, and 3 and Olim 1 and 2) and also considered 496 MED nodes. All MED node sequence counts per sample were input into the 'corncob' program, which modeled relative abundances of MED nodes. Differential abundance was modeled as a function of either (1) percent coral cover, (2) percent macroalgal cover, or (3) island/atoll (Kosrae vs. Olimarao). The parametric Wald test was used to test the hypothesis that the relative abundance of a given MED node changed significantly with respect to the variable (percent coral cover, percent algal cover, site category), and the Benjamini-Hochberg false discovery rate (FDR) correction was applied to account for multiple comparisons, with the cutoff at 0.05 .

Sequence data are available at NCBI's Sequence Read Archive under BioProject IDs PRJNA636810 and PRJNA27914, and representative sequences for each MED are provided in Table S2.
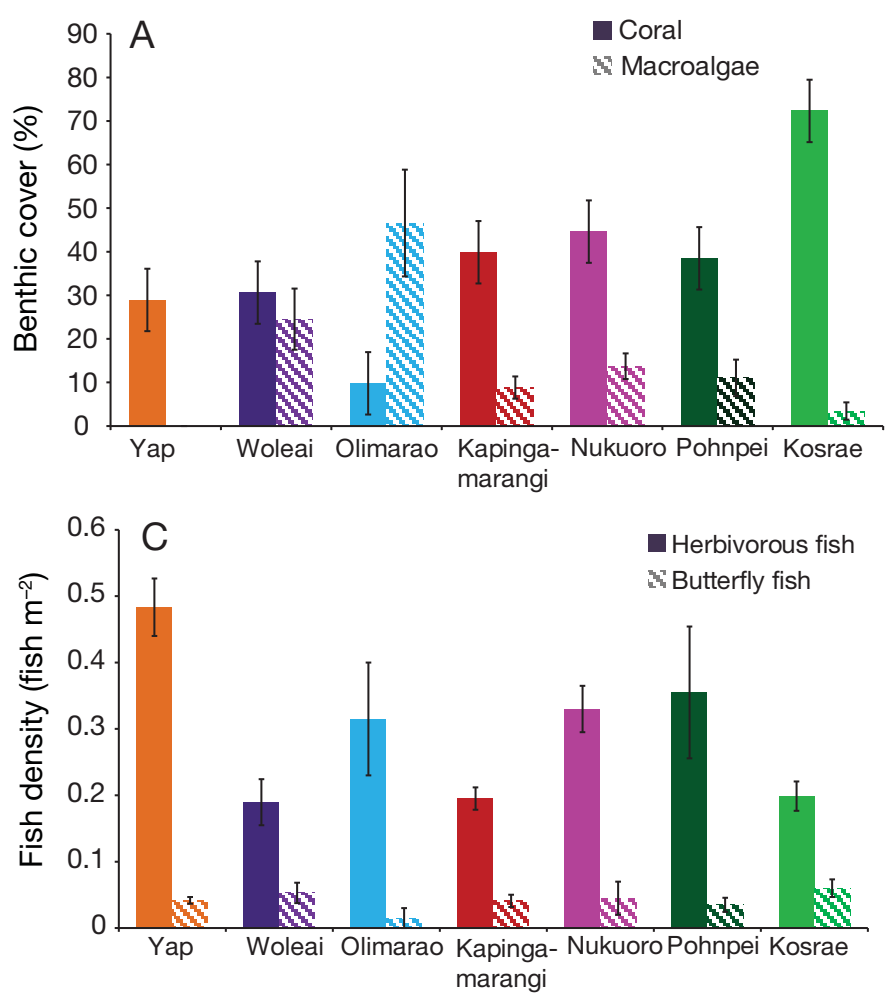

\subsection{Statistical analyses}

Statistical comparisons of reef and environmental data were conducted using SigmaPlot v14 (Systat Software). For $t$-tests and regressions, the data were verified as normal prior to analyses using ShapiroWilk normality tests and Brown-Forsythe equal variance tests. If normalization failed, Mann-Whitney rank sum tests were used. Two-way ANOVA tests were applied to either raw or square root transformed (for normalization) data in order to test the impact of site, depth, and site $\times$ depth interactions on reef-water nutrient and microbial parameters.

\section{RESULTS}

\subsection{High coral cover and low fish abundance on reefs}

Across the islands and atolls of Micronesia, hard coral primarily dominated reefs (Fig. 1I,J), with average coral cover ranging from 7 to $73 \%$ (mean \pm SD: $36.9 \pm 22.3 \%$ ) on reefs per island or atoll, with the highest coverage observed on Kosrae Island reefs
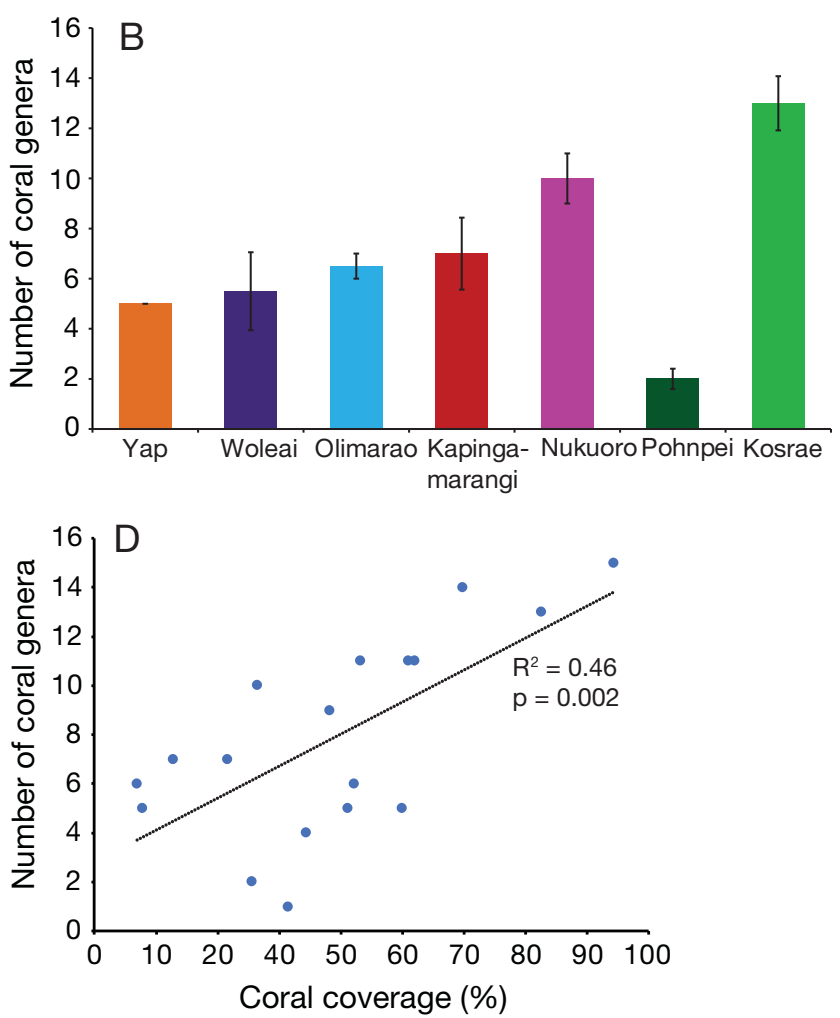

Fig. 2. Macro-organism abundance and diversity on reefs of each island or atoll. (A) Average abundance of coral and macroalgae, (B) average coral richness (by genera), and (C) density of herbivorous and butterflyfish and (D) relationship between coral genera and coral coverage on the reefs. Error bars represent standard deviation over 2-6 reef sites per island or atoll. Differently colored bars indicate site groupings (1-6 sites per island/atoll; see Table 1) 
(variability in coverage presented in Fig. 2A). Macroalgal cover was $10 \%$ or less on Kapingamarangi, Nukuoro, Pohnpei, and Kosrae reefs, and higher on Woleai and Olimarao at 25 and $50 \%$ cover, respectively, with a mean coverage of $15.2 \pm 15.5 \%$ across all island or atoll reefs (macroalgae were not quantified on Yap) (Figs. 1K \& 2A). Coral diversity was assessed by richness of genera, and this ranged from 2 to 13 genera per island or atoll and was highest on Kosrae and lowest on Pohnpei (Fig. 2B; Table S3). Across the Micronesian reefs, there was a significant relationship between coral coverage and richness of coral genera (regression analysis, $\mathrm{R}^{2}=0.46, \mathrm{p}=0.002$; Fig. 2D). Average abundances of herbivorous fish on the reefs ranged from 0.19 to 0.48 fish $\mathrm{m}^{-2}$ (mean: $0.26 \pm 0.14$ ), with the highest abundance on Yap and lowest abundances on Woleai, Kapingamarangi, and Kosrae (Fig. 2C). Corallivorous fish (butterflyfishes) abundances ranged from an average of 0.02 to 0.06 fish $\mathrm{m}^{-2}$ (mean: $0.04 \pm 0.02$ ), with lowest abundance on Olimarao reefs, which also had the lowest coral cover (Fig. 2C). Significant relationships were also observed between fish abundances and the benthic community. Specifically, regression analysis showed a relationship between increasing butterfly fish abundance and increasing coral cover $\left(\mathrm{R}^{2}=0.163, \mathrm{p}=0.09\right)$. In contrast, butterfly fish abundance decreased with increasing macroalgae $\left(\mathrm{R}^{2}=0.40\right.$, $\mathrm{p}=0.006)$. A significant positive relationship existed between coral richness and herbivore density $\left(\mathrm{R}^{2}=\right.$ $0.179, \mathrm{p}=0.08)$. There were no significant relationships observed between hard coral cover and herbivore abundance; coral richness and butterfly fish abundance; or herbivore density and macroalgae abundance $\left(\mathrm{R}^{2}=0.009-0.02, \mathrm{p}>0.1\right)$.

\subsection{Consistent physicochemical parameters across reefs}

Temperature at the reefs ranged from 29.1 to $31.8^{\circ} \mathrm{C}$ (mean $\pm \mathrm{SD}: 30.1 \pm 0.6^{\circ} \mathrm{C}$ ) and was highest at the southernmost reefs of Kapingamarangi atoll (Table S1). Salinity was similar throughout the reefs (34.1-34.7; mean: $34.4 \pm 0.14)$, and oxygen was saturated (near $100 \%$ ) at all sites (Table S1).

\subsection{Nutrient concentrations indicate oligotrophic conditions, with low TOC at high coral cover reefs}

Inorganic nutrient concentrations were consistently low across the reef sites. Nitrate + nitrite varied from detection limits $(0.07 \mu \mathrm{M})$ to $2.0 \mu \mathrm{M}$ (mean \pm SD: 0.58 $\pm 0.67 \mu \mathrm{M})$, reached the highest concentrations at the Nukuoro and Pohnpei reef depths (Fig. 3A), and significantly related to island/atoll ( $p=0.004$, Table 2). Ammonium concentrations ranged from the detection limit $(0.02 \mu \mathrm{M})$ to $0.23 \mu \mathrm{M}$ (mean: $0.07 \pm 0.05 \mu \mathrm{M}$ ) (Fig. 3B). Phosphate varied from 0.05 to $0.20 \mu \mathrm{M}$ (mean: $0.11 \pm 0.04 \mu \mathrm{M}$ ) across the reefs (Fig. 3C), and was significantly related to island/atoll $(\mathrm{p}=0.001$, Table 2). Concentrations of silicate ranged from 0.80 to $1.86 \mu \mathrm{M}$ (mean: $1.10 \pm 0.20 \mu \mathrm{M}$ ) at the reef sites and were highest in Pohnpei island surface waters (Fig. 3D). Across the reefs, surface and reef depth inorganic nutrient concentrations were not significantly different according to depth category or island/ atoll $\times$ depth interactions $(\mathrm{p}>0.1$; Table 2$)$.

TOC concentrations in the reef waters ranged from 59.8-104.4 $\mu \mathrm{M}$ (mean: $72.2 \pm 8.7 \mu \mathrm{M}$ ) (Fig. 3E). The highest concentration of TOC was measured in the surface waters of Kap 3 (Fig. 1F), a lagoon in the Kapingamarangi atoll. The 3 Kosrae Island reefs, which had the highest abundance and diversity of hard coral among all islands, consistently had concentrations of TOC below the mean for the study, ranging from 59.8 to $67.9 \mu \mathrm{M}$ (Fig. 3E). However, when comparing all islands and atolls, there was no trend between TOC concentrations and coral abundance (linear regression, $\mathrm{R}^{2}=0.140, \mathrm{p}>0.1$ ). TON concentrations were variable across the reef locations, ranging from 1.4 to $5.5 \mu \mathrm{M}$ (mean: $4.0 \pm 1.1 \mu \mathrm{M}$ ), with the lowest concentrations measured in the reef depth waters of Nukuoro (Nuk 1) and consistently high concentrations in the surface and reef depth waters of Kosrae (4.5-5.3 $\mu \mathrm{M}$; mean: $5.0 \pm 0.26 \mu \mathrm{M}$; Fig. 3F). We found no significant relationship between TON and coral abundance $\left(\mathrm{R}^{2}=0.04, \mathrm{p}>0.1\right)$.

\subsection{Abundant picocyanobacteria in reef waters}

Abundances of specific microbial groups measured using flow cytometry were relatively consistent across the reefs. Prochlorococcus ranged from non-detectable (Poh 2, surface) to 85400 cells $\mathrm{ml}^{-1}$ (Kap 6, reef depth) with a mean \pm SD of $35400 \pm 20400$ cells ml $^{-1}$ for all samples (Fig. 4A). Throughout all of the reef sites, Prochlorococcus were present at significantly higher concentrations at the reef depth compared to the surface waters (reef depth: $44300 \pm 19100$ cells

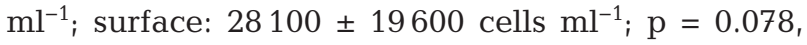
Table 2). Synechococcus concentrations were variable across the reefs, ranging from $660 \pm 19 \mathrm{cells} \mathrm{ml}^{-1}$ (Kos 3, surface) to $175000 \pm 120$ cells ml $^{-1}$ (Poh 2, surface) with a mean of $28000 \pm 39400$ cells ml ${ }^{-1}$ for all 

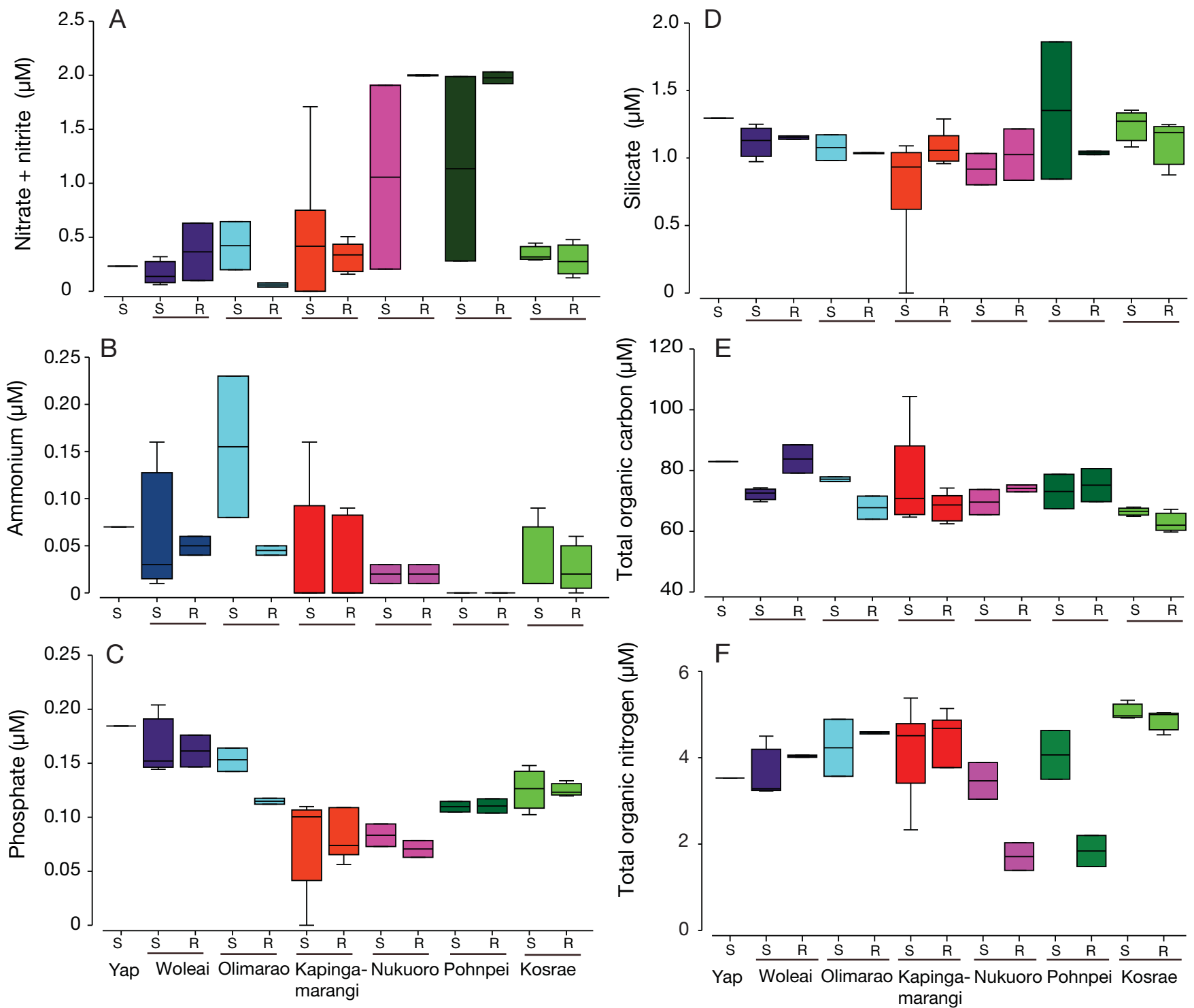

Fig. 3. Inorganic nutrient concentrations in Micronesian reef waters. Concentrations of (A) nitrate + nitrite, (B) ammonium, (C) phosphate, (D) silicate, (E) total organic carbon, and (F) total organic nitrogen grouped by surface (S) and reef depth (R) waters per island or atoll (1-6 sites; see Table 1). Colors designate the site groupings, the black bar across the boxplot represents the median value and the whiskers extend to values at 1.5 times the interquartile range (delimited by the box)

samples (Fig. 4B). Picoeukaryotes were generally low in abundance at the reefs, ranging from $160 \pm 28$ cells $\mathrm{ml}^{-1}$ (Kap 2, surface) to $7800 \pm 850$ cells ml $^{-1}$ (Poh 2, surface) with a mean of $1300 \pm 1400$ cells ml $^{-1}$ across the reefs (Fig. 4C). Unpigmented cells, interpreted as heterotrophic bacteria and archaea, displayed variability throughout the reef sites, ranging from $76900 \pm 2270$ cells ml $^{-1}$ (Kap 2, surface) to $1121000 \pm$ 16100 cells ml $^{-1}$ (lagoon at Kap 3, surface), with mean concentrations of $437000 \pm 193000$ cells ml $^{-1}$ throughout the reefs (Fig. 4D). Concentrations of all prokaryotes (unpigmented cells + Synechococcus + Prochlorococcus) generally followed the same patterns per site and depth as the unpigmented cells
(Fig. 4E). Across all of the reefs, abundances of Synechococcus, picoeukaryotes, and unpigmented cells were not related to island/atoll, depth category, or island/atoll $\times$ depth interactions (Table 2).

In order to estimate potential metabolic contributions of the picoplankton to the reefs, we used the flow cytometry measurements to compare the ratio of heterotrophic to autotrophic, prokaryotic cells (unpigmented cells / [Prochlorococcus + Synechococcus]). This comparison showed that on average, the reefs contained 9:1 heterotrophic to autotrophic cells (Fig. 4F). The Kosrae reefs had the highest ratio of heterotrophic to autotrophic cells at both surface and reef depths (Fig. 4F). Across all reefs, the ratio of het- 
Table 2. Two-way ANOVA of reef seawater nutrient and cell abundance parameters, by island and depth interactions ( $p<0.1$ are bolded). NA: not applicable

\begin{tabular}{|c|c|c|c|c|c|c|}
\hline \multirow{2}{*}{ Parameter } & \multicolumn{2}{|c|}{ Island $(\mathrm{df}=5)$} & \multicolumn{2}{|c|}{ Depth $(\mathrm{df}=1)$} & \multicolumn{2}{|c|}{ Island $\times$ Depth $(\mathrm{df}=5)$} \\
\hline & $F$ & $\mathrm{p}$ & $F$ & $\mathrm{p}$ & $F$ & $\mathrm{p}$ \\
\hline $\mathrm{NO}_{3}^{-}+\mathrm{NO}_{2}^{-}$ & 5.00 & 0.004 & 0.576 & $>0.1$ & 1.22 & $>0.1$ \\
\hline $\mathrm{NH}_{4}^{+}$ & 0.97 & $>0.1$ & 0.74 & $>0.1$ & 2.14 & $>0.1$ \\
\hline $\mathrm{PO}_{4}^{3-}$ & 11.96 & 0.001 & 1.99 & $>0.1$ & 0.51 & $>0.1$ \\
\hline TOC & 1.58 & $>0.1$ & 0.03 & $>0.1$ & 1.23 & $>0.1$ \\
\hline TON & 2.13 & $>0.1$ & 1.68 & $>0.1$ & 1.04 & $>0.1$ \\
\hline Silicate & 0.84 & $>0.1$ & 0.13 & $>0.1$ & 0.65 & $>0.1$ \\
\hline Prochlorococcus & 1.30 & $>0.1$ & 3.46 & 0.078 & 0.65 & $>0.1$ \\
\hline Synechococcus & 1.91 & $>0.1$ & 0.81 & $>0.1$ & 0.56 & $>0.1$ \\
\hline Unpigmented picoplankton & 0.98 & $>0.1$ & 0.31 & $>0.1$ & 0.26 & $>0.1$ \\
\hline Picoeukaryotes & 1.78 & $>0.1$ & 0.10 & $>0.1$ & 1.23 & $>0.1$ \\
\hline Chlorophyll a & 1.20 & $>0.1$ & NA & NA & NA & NA \\
\hline Heterotrophic: autotrophic prokaryotes & 3.10 & 0.033 & 0.30 & $>0.1$ & 0.139 & $>0.1$ \\
\hline Microbial richness & 1.30 & $>0.1$ & 0.28 & $>0.1$ & 3.75 & 0.015 \\
\hline
\end{tabular}

erotrophic to autotrophic cells did not differ significantly according to island/atoll, depth category, or island/atoll $\times$ depth interactions (Table 2).

Total chlorophyll was only measured in the surface waters, and concentrations ranged between 0.001 and $0.219 \mu \mathrm{g} \mathrm{l}^{-1}$ (mean $0.099 \pm 0.055 \mu \mathrm{g} \mathrm{l}^{-1}$ ) at the reef sites, with the lowest concentration at the open water site and highest at Woleai atoll (Wole 3) (Fig. 4G). Pigment concentration data were used to estimate the proportion of the pigmented cells corresponding to micro-, nano-, and picoplankton communities. For all reef waters, picoplankton were responsible for the majority of the chlorophyll biomass (range of $54-82 \%$, mean of $71 \pm 8.7 \%$ of chlorophyll biomass), followed by nanoplankton (range of 3-33\%, mean of $17 \pm 6.1 \%$ ) and then microplankton (range of $5-32 \%$, mean of $13 \pm 8.1 \%$ ) (Table S1; individual pigment concentrations are also presented).

\subsection{Reef depth microbial richness related to benthic reef community}

Richness of reef-water microorganisms, as assessed by number of MED nodes from SSU rRNA gene amplicons of bacteria and archaea, was generally consistent throughout the reef waters, with values ranging from 267 to 441 MED nodes with an average of $393 \pm 33$ MED nodes (Fig. 5A). Nukuoro $(\mathrm{n}=2)$ and Kosrae $(\mathrm{n}=3)$ reefs showed the highest microbial richness (391-430 and 377-434 MED nodes, respectively) compared to the other reefs (Fig. 5A). The 2-way ANOVA revealed an island/ atoll $\times$ depth interaction for microbial richness $(\mathrm{p}=$ 0.015 , Table 2).
Linear regression analysis indicated that reef depth microbial richness was positively correlated with percentage of hard coral coverage $\left(R^{2}=0.33, p=0.013\right.$; Fig. 5B) as well as negatively related to percent macroalgal coverage $\left(R^{2}=0.30, p=0.023\right.$; Fig. $\left.5 C\right)$. These trends between microbial alpha diversity at reef depth and coral and macroalgal cover were also examined for Shannon and Simpson's diversity indices, and the relationships were not significant $\left(R^{2}=0.04-\right.$ $0.10 ; \mathrm{p}>0.1$ ). No relationships were detected between coral diversity or densities of other reef life (herbivores or butterflyfish) and microbial richness $\left(\mathrm{R}^{2}=0.05 ; \mathrm{p}>0.1\right)$. There was a relationship between increasing number of MED nodes and increasing silicate concentrations $\left(R^{2}=0.113, p=0.056\right)$, but no relationships were detected between microbial diversity and concentrations of phosphate, nitrate+nitrite, ammonium, TON, or TOC $\left(\mathrm{R}^{2}=0.008-0.022, \mathrm{p}>0.1\right)$.

\subsection{Reef seawater microbial communities are related to biogeographical and environmental factors}

Comparison of microbial community composition using the Bray-Curtis dissimilarity index demonstrated that communities were $65-85 \%$ similar, with the exception of surface waters from a Pohnpei reef (Poh 2), which was only $42 \%$ similar to the other reef waters (Fig. 6A). Reefs that were most similar in microbial composition included the Kosrae Island sites, which clustered together with $85 \%$ similarity, and the Kapingamarangi atoll sites with $75 \%$ similarity, except for 1 benthic sample (Kap 2, Fig. 6A). PERMANOVA of the effect of island/atoll and depth 

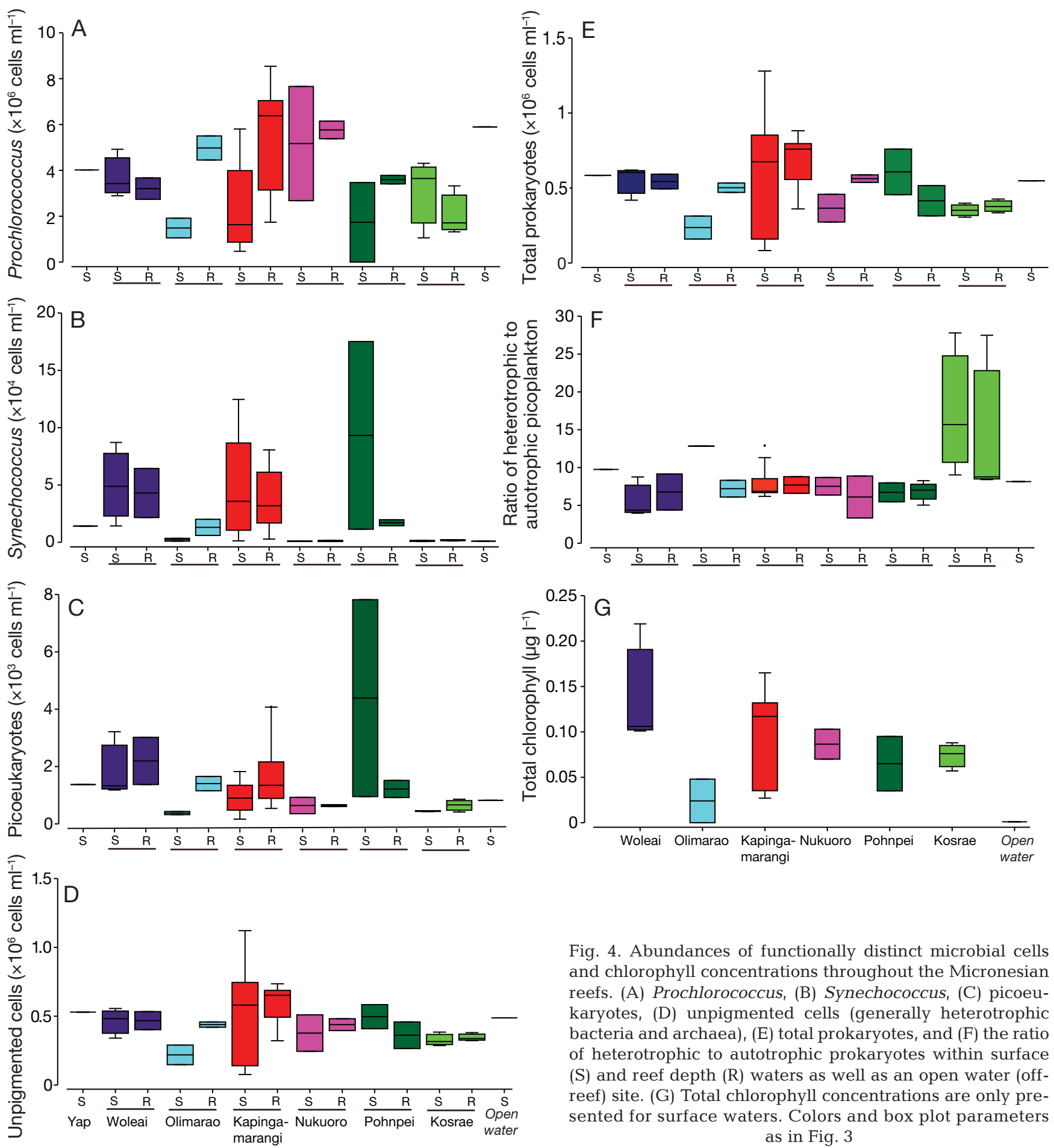

on the microbial community composition showed a significant relationship between island/atoll in reef depth (pseudo- $F=2.9127$, Monte Carlo $p=0.002$ ) as well as surface waters (pseudo- $F=2.6749$, Monte Carlo $p=0.002$, Table S4). Sampling depth, without consideration of island/atoll, did not significantly influence microbial community composition (pseudo-

Fig. 4. Abundances of functionally distinct microbial cells and chlorophyll concentrations throughout the Micronesian reefs. (A) Prochlorococcus, (B) Synechococcus, (C) picoeukaryotes, (D) unpigmented cells (generally heterotrophic bacteria and archaea), (E) total prokaryotes, and $(\mathrm{F})$ the ratio of heterotrophic to autotrophic prokaryotes within surface (S) and reef depth (R) waters as well as an open water (offreef) site. (G) Total chlorophyll concentrations are only presented for surface waters. Colors and box plot parameters as in Fig. 3

$F=0.90961$, Monte Carlo $\mathrm{p}=0.427$ ). PERMANOVA pairwise comparisons suggested that the island/atoll difference was mostly due to differences in surface and reef depth microbial communities at Kapingamarangi atoll compared to Kosrae, Nukuoro, Olimarao, and Woleai as well as differences between Kosrae and Woleai sites ( $p<0.1$; Table S4). PERM- 

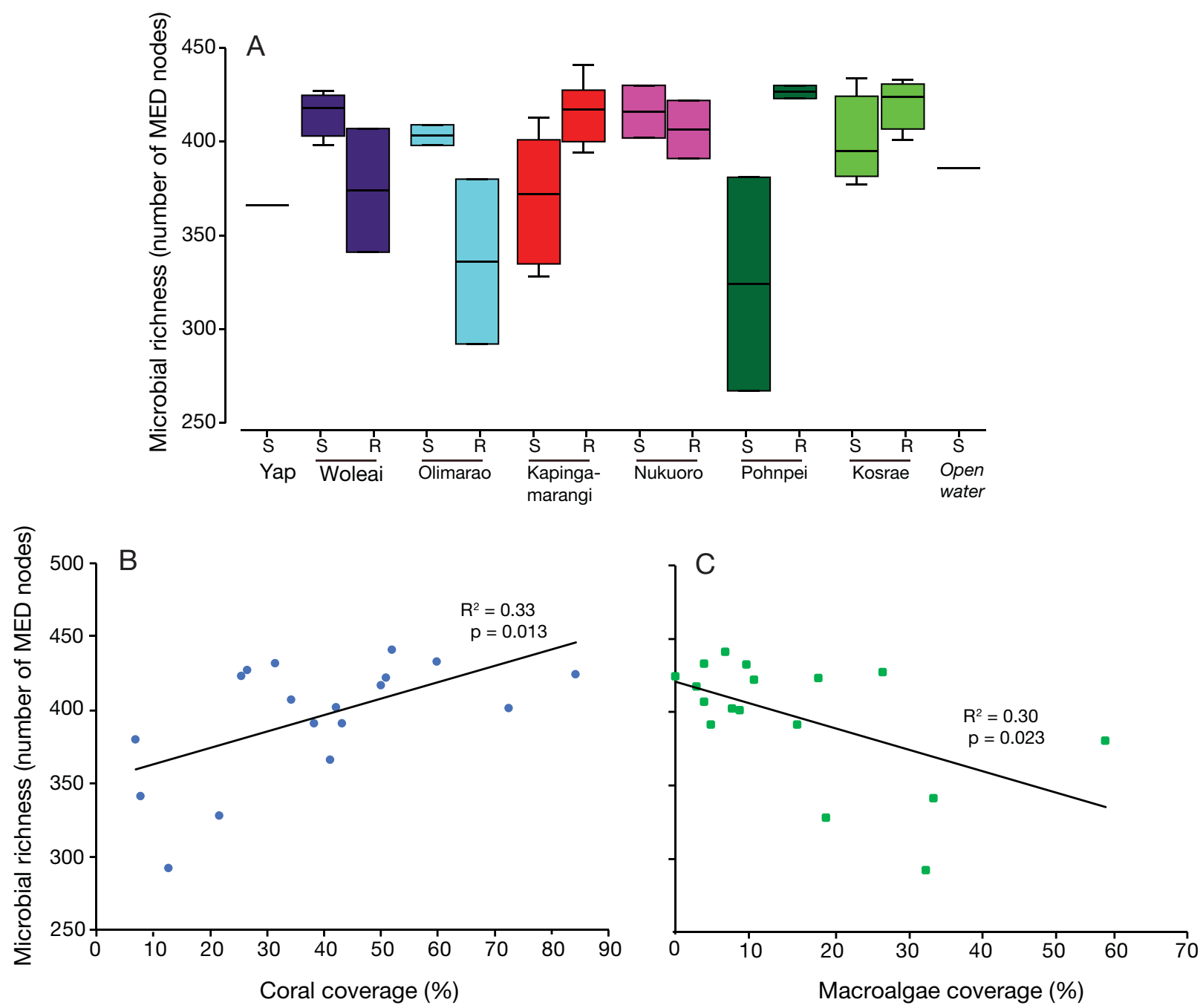

Fig. 5. (A) Reef seawater microbial richness for each island and atoll according to depth. Microbial richness at the reef depth was significantly related to the abundance of (B) coral and (C) macroalgae comprising the reefs. Microbial richness is represented by number of MED nodes obtained from SSU rRNA gene amplicons of bacteria and archaea. In panel (A), 'S' represents surface samples and ' $R$ ' represent reef depth samples. Only surface waters were collected for Yap and the open-water site. Colors and box plot parameters as in Fig. 3

DISP also demonstrated that these relationships were not related to the degree of beta dispersion $(\mathrm{p}>0.1$; Table S4). Additionally, there were differences in reef depth community composition between Kapingamarangi and Pohnpei as well as Kosrae and Pohnpei (PERMANOVA $\mathrm{p}<0.1$ with PERMDISP $\mathrm{p}>0.1$; Table S4). For the open-water site, surface water microbial community composition was only significantly different from reef-water microbial communities at Kapingamarangi atoll (PERMANOVA $\mathrm{p}=0.025$ with PERMDISP $\mathrm{p}>0.1$; Table S4).

To further examine the relationship between microbial community composition and reef and environmental features, an nMDS analysis of the microbial community composition (Bray-Curtis dissimilarity) was conducted and overlaid with vectors represent- ing other reef and environmental features (Fig. 6B). This analysis showed that the Poh2 surface water microbial community was distinct from the other reefwater microbial communities, as evidenced by the symbol that is plotted outside of the predictor variable circle (Fig. 6B). Kapingamarangi atoll reef-water microbial communities, which were closest to the equator, correlated with temperature, silicate concentrations, as well as abundances of unpigmented picoplankton, Synechococcus, and picoeukaryotes (Fig. 6B). Kosrae reef microbial communities were also correlated with these same factors (temperature, silicate concentrations, and abundances of unpigmented picoplankton, Synechococcus, and picoeukaryotes) as well as with Prochlorococcus abundance, concentrations of TOC and TON, and ratios of 
A

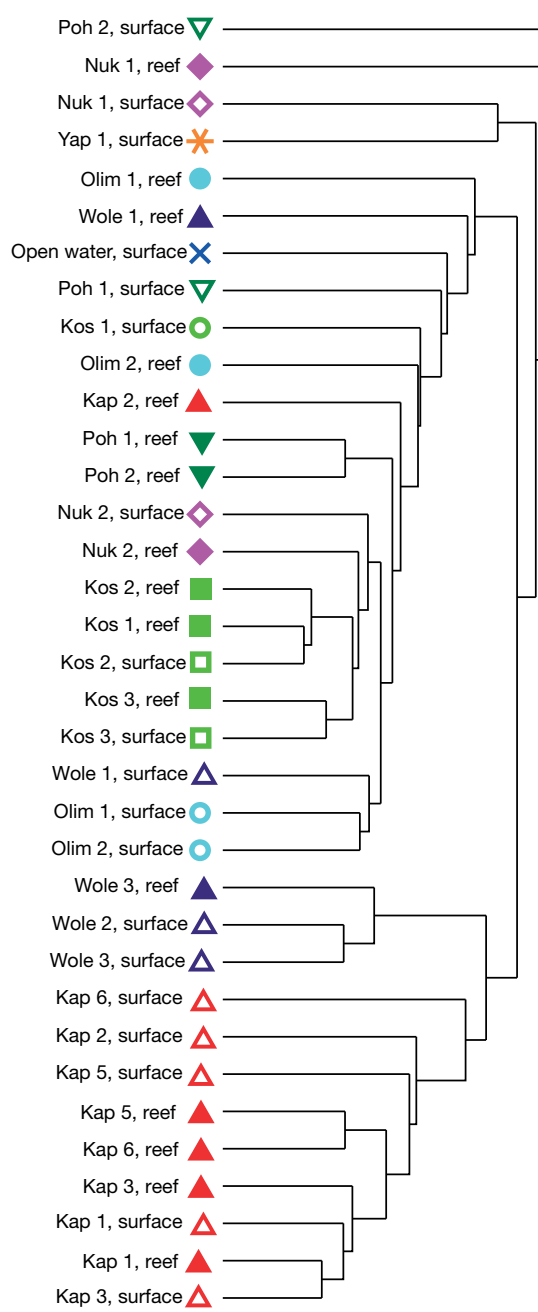

Similarity

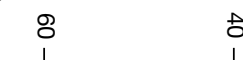

t $\dot{0}$

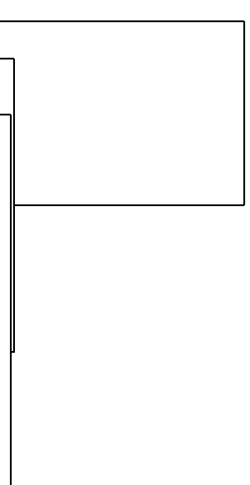

* Yap (surface)

$\Delta$ Woleai (surface)

$\Delta$ Woleai (reef-depth)

Olimarao (surface)

Olimarao (reef-depth)

$\Delta$ Kapingamarangi (surface)

$\Delta$ Kapingamarangi (reef-depth)

$\checkmark$ Nukuoro (surface)

Nukuoro (reef-depth)

$\nabla$ Pohnpei (surface)

$\checkmark$ Pohnpei (reef-depth)

$\square$ Kosrae (surface)

Kosrae (reef-depth)

$\times$ Open water

Fig. 6. Comparison of reef-water microbial communities and relationship to environmental factors. (A) Cluster dendrogram of reef-water bacterial and archaeal communities, according to island or atoll and sampling depth. (B) Nonmetric multidimensional scaling (nMDS) analysis of reef-water bacterial and archaeal communities, according to island or atoll and depth, with vector overlays representing multiple correlations between ordination axes and environmental variables. Clustering was conducted using group average linkages on Bray-Curtis dissimilarity indices computed from the square-root transformed relative abundances of small subunit rRNA gene amplicons grouped into minimum entropy decomposition nodes. Only surface water from 1 Yap site was collected. TOC (TON): total organic carbon (nitrogen)

heterotrophic to autotrophic microorganisms (Fig. 6B). Comparison of the environmental parameters to microbial community composition in surface waters using BEST analysis showed significant relationships between community composition and ammonium and silicate concentrations, as well as latitude (rho = 0.546, $\mathrm{p}=0.045$ ). Reef depth microbial community composition was related to latitude and longitude (rho $=0.519, \mathrm{p}<0.02$ ).

RELATE analysis was used to further investigate the relationship between geographical distance and the composition of the microbial community. For reef depth microbial communities, there was a significant relationship with geographical distance (rho $=0.253$, $\mathrm{p}=0.032$ ). In contrast, RELATE analysis showed no significant relationship between surface water microbial community composition and geographic distance between the sites (rho $=0.092, \mathrm{p}=0.181$ ). We also conducted the RELATE analysis to examine relationships between geographic distance and microbial community composition over a smaller spatial scale at the Kosrae and Kapingamarangi sites. Reef water 
from both of these locations was sampled at least 3 or more times at different intra-island sites surrounding each island or atoll (within island/atoll distances: 0.15-5.36 km; between islands/atoll distances: $1021-$ $1028 \mathrm{~km})$. For both surface and reef depth waters, geographic distance had a significant impact on the microbial community structure (i.e. intra-island sites had more similar microbes than sites between Kosrae and Kapingamarangi) (reef depth: rho $=0.507, \mathrm{p}=$ 0.033; surface: rho $=0.807, \mathrm{p}=0.002$ ).

\subsection{Reef waters are dominated by picocyanobacte- ria and bacteria common to oligotrophic regions}

Reef-water bacterial and archaeal composition, as assessed using SSU rRNA gene amplicons, showed a high abundance of picocyanobacteria in all reef waters. Picocyanobacterial taxa mostly consisted of Synechococcus and Prochlorococcus (35-50\% collective relative abundance; Fig. 7). The relative sequence abundances of Synechococcus were at least 3-fold greater than Prochlorococcus (Fig. 7), whereas cellular concentrations identified using flow cytometry showed Synechococcus to be about twice as abundant as Prochlorococcus (Fig. 4A,B). Sequences associated with the SAR11 clade regularly made up $20-30 \%$ of the microbial community in the reef waters. Rhodospirillales, Oceanospirillales, Acidmicrobiales, Rickettsiales, and Rhodobacterales affiliated sequences were consistently represented in all samples (Fig. 7). Of these major taxonomic groups, the open water (non-reef) site displayed a similar profile, but with fewer Synechococcus and Thermosplasmatales (Euryarchaeaota) compared to the reef sites (Fig. 7). Generally, taxonomic profiles of microbial communities were similar between the surface and reef depth seawater at each site.

We used SIMPER analysis to identify specific MED nodes that contributed to island- or atoll-based microbial community similarity. The identified taxa were generally similar between the islands and atolls, and included members of the Prochlorococcus (uncultured and MIT9313), Synechococcus CC9902, SAR11 (clades I, Ia, Ib, and II), SAR86, SAR116, AEGEAN-169 marine group, as well as sequences affiliated with the 'Candidatus Actinomarina' (Table S5). Despite the similarities, relative abundances of microbial taxonomic groups were distinctly shifted at one of the Nukuoro sites (Nuk 1), which contained fewer cyanobacteria (20\%) compared to the other reefs (40-50\% cyanobacteria)

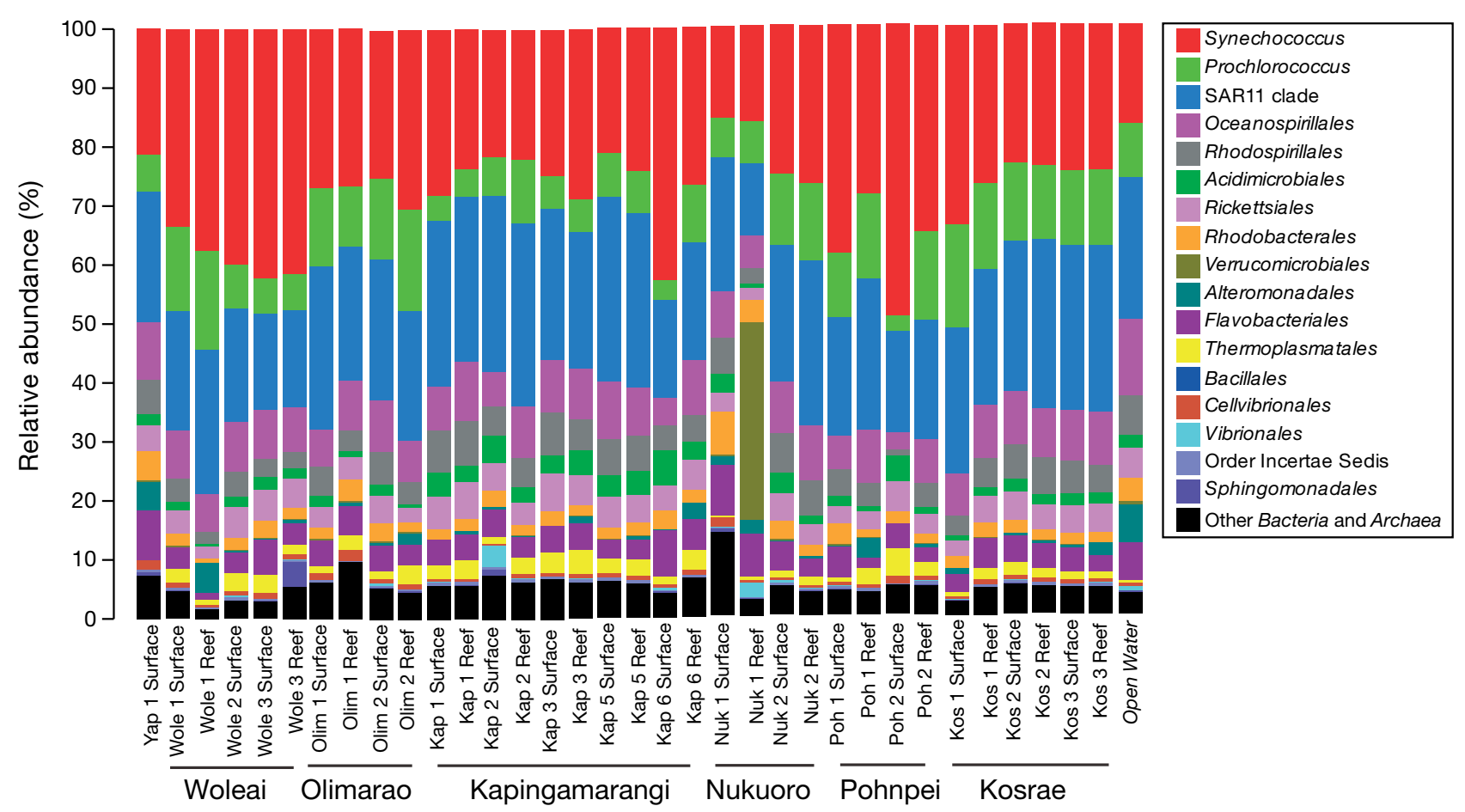

Fig. 7. Relative abundances of the most prevalent taxonomic groups of bacteria and archaea present within the reef waters, as examined using small subunit rRNA gene amplicons. Taxa are generally represented by family, with the more abundant genera and clades specifically noted (e.g. Synechococcus, Prochlorococcus, SAR11 clade, etc.) 
(Fig. 7). The Nuk 1 reef depth microbial community also harbored elevated relative abundances of Verrucomicrobiales (primarily Rubritalea) $(35 \%)$ compared to the other sites $(<1 \%)$ (Fig. 7).

\subsection{Microbial species indicative of coral- and macroalgal-dominated reefs}

In order to further discern possible contributions of the benthic reef features to the overlying reef depth microbial community, we used differential abundance analyses implemented in the R package 'corncob' to identify specific MED nodes (MEDs) that were significantly differentially enriched in relative abundance on the coral- and macroalgal-dominated reefs from 16 sites. Coral-dominated reefs were positively enriched in 9 MEDs that were associated with primarily copiotrophic lineages of bacteria, including unclassified Flavobacteriaceae, Leisingera, Owenweeksia, Vibrio, OM27 clade, Desulfuromondales, and the NS4 marine group (Fig. 8A). In contrast, macroalgal-rich reefs were only positively enriched with 3 MEDs, including an unclassified Alphaproteobacteria as well as 2 Prochlorococcus MEDs (Fig. 8B).

A differential abundance analysis comparison of reef depth waters was conducted to specifically compare MEDs from the coral-dominated reefs from Kosrae (mean coral cover $72 \%$; $\mathrm{n}$ $=3$ sites) to the most macroalgal-dominated sites of Olimarao (mean macroalgal cover $46 \% ; \mathrm{n}=2$ sites). This analysis showed that 74 MEDs contributed to differences between these microbial communities. Microbial taxa differentially abundant on the Kosrae reefs (i.e. the most positive estimate values) included Marinobacterium, Owenweeksia, an unclassified Gammaproteobacteria, NS5 marine group, SAR11 clades I, Ib, II, and III, an unclassified Cryomorphaceae, Desulfuromonadales group PB19, SAR116, SAR86, AEGEAN-169, 'Candidatus Actinomarina', Marinicella, and the SAR92

B
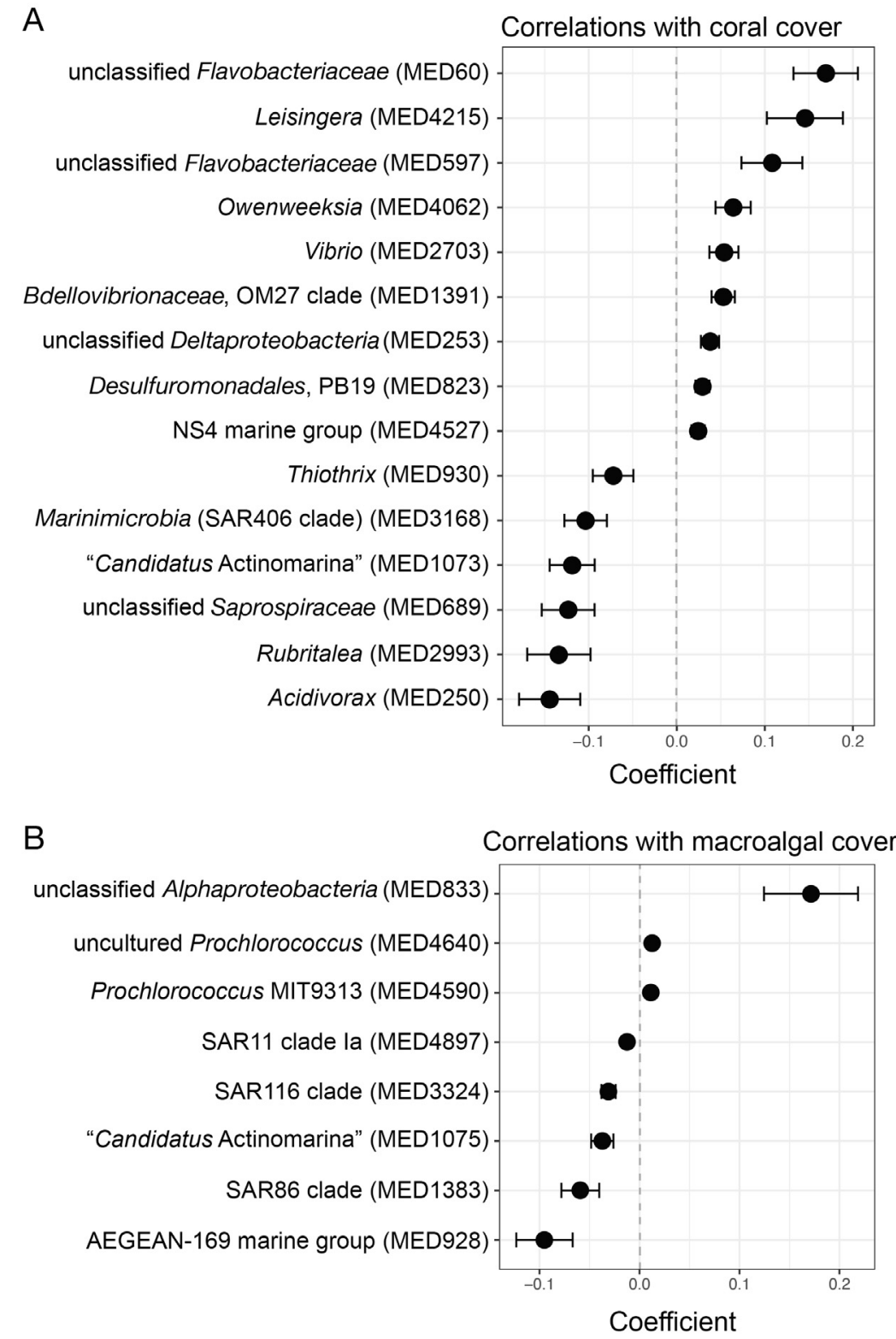

Fig. 8. Differentially abundant microbial taxa (minimum entropy decomposition, MED) as a function of (A) coral coverage and (B) macroalgal coverage, assessed using reef depth microbial communities with the analysis in the $\mathrm{R}$ package 'corncob' (v 0.1.0). The relative abundance of each MED node was modeled as a function of the percentage of coral and macroalgal coverage, and the coefficient indicates the change in MED node relative abundance, with the positive coefficients most related to coral (A) and macroalgal (B) coverage

clade (Table S6). For the Olimarao reefs, differentially abundant associated microbial taxa (with the most negative estimate values) included unclassified Rhodobacteraceae, NS9 marine group, OM6 clade, Synechococcus, Alcanivorax, Roseibacillus, several Marine Group II and III Euryarchaeota groups, SAR11 clades I, Ib, and II, Pirellula, unclassified Dadabacteriales, and the SAR324 clade (Table S6). 


\section{DISCUSSION}

This is the first study to examine the microbial ecology of the reef waters within Micronesia. Overall, we found high similarity in the composition of the microbial communities as well as in the concentrations of nutrients and organic matter between surface and reef depth waters, and ammonium and silicate concentrations were linked to microbial community composition in surface waters. Microbial richness was significantly related to island/atoll and depth category interactions and was positively correlated with coral cover. Reefs with high coral cover were enriched in distinct copiotrophic and coral-associated microbial lineages, suggesting that the reef macro-organismal community is tightly linked to the microbial ecology in the overlying waters. Further, biogeographic distance-related factors were significantly related to the composition of the reef depth microbial community. We also noted unique features at the coral-dominated Kosrae reefs that provide additional insights into reef community microbial biogeochemistry.

\subsection{Context of Micronesian reefs and nutrient and organic matter concentrations}

The reefs surveyed in Micronesia all harbored generally high abundances of coral. Kosrae reefs hosted the highest abundances (up to $77 \%$ coverage) of coral, consistent with previous observations (Richards 2015). More generally across the islands and atolls, coral and macroalgal coverages were in line with previous observations on other Micronesian reefs including Pohnpei, Chuuk, and Yap Islands (Abraham et al. 2004, Goldberg et al. 2008). Comparing Micronesian reefs more globally, the coverage of coral we observed in Micronesia is similar to that of the northern Line Islands (Sandin et al. 2008) but much higher than many other global reefs, including the Great Barrier Reef (mean 13.8\%) (De'ath et al. 2012) and Caribbean reefs (<10\%) (Gardner et al. 2003). Thus, our study provides a reference for microbial and nutrient parameters on reefs with high coral cover. We found that the densities of herbivorous fish were generally low, consistent with previous observations on Micronesian reefs (Mumby et al. 2013). The Micronesian reef fisheries are not sustainably managed (Houk et al. 2012, Rhodes et al. 2015), and fish densities could be related to the presence of human settlements on the islands as well as foreign fishing interests. Herbivorous fish abundances were highest on the most populated islands of Pohnpei and
Yap (Table 1), suggesting that local management practices that protect herbivorous fish are having a measurable impact. Corallivorous fish were lowest on the macroalgal-dominated Olimarao atoll, reflective of the fewer corals available for feeding. Overall, our results reflect the microbial and nutrient parameters of these Micronesian reefs with high coral coverage and low abundances of fish.

The concentrations of inorganic nutrients measured on the Micronesian reefs were within the ranges reported for other reef locations and suggest a rapid turnover of the nutrient pools by microorganisms and other reef biota. Concentrations of phosphate and inorganic nitrogen were slightly higher in Micronesian seawater compared to measurements collected from reef seawater across Cuba and the Florida Keys (Weber et al. 2020), yet similar to concentrations in coastal Hawaii (Apprill \& Rappé 2011, Yeo et al. 2013) and the Line Islands (Sandin et al. 2008, Kelly et al. 2014), which potentially reflect reef or larger ocean basin-related differences. TOC concentrations in the present study averaged $72 \mu \mathrm{M}$, and were lower than concentrations measured on Cuban and Florida Keys reefs (75-130 $\mu \mathrm{M}$ ) (Weber et al. 2020) and slightly lower than Hawaiian reefs $(73-79 \mu \mathrm{M})$ (Apprill \& Rappé 2011). Concentrations of TON (mean $4 \mu \mathrm{M}$ ) were similar to the offshore Cuban reefs, and much lower than nearshore reefs $(>10 \mu \mathrm{M})$ in the Florida Keys (Weber et al. 2020).

\subsection{Context of Micronesian reef-water microbiology}

Abundances of photosynthetic and heterotrophic (unpigmented) microbial cells varied throughout the reefs, which could be related to the quality and quantity of inorganic nutrients and organic matter in the reef waters as well as subtle differences in physicochemical properties. Prochlorococcus and Synechococcus abundances in Micronesian reef waters were typical of forereef-type and coastal locations measured in Cuba and Florida reefs (Weber et al. 2020), suggesting that photosynthetic metabolisms are consistently important features on coral reefs. Throughout the Micronesian reefs, Prochlorococcus were significantly elevated at the reef depths compared to the surface waters, which was seen at one site in a previous study in St. John, US Virgin Islands (Weber \& Apprill 2020). This trend may be related to the decreased light levels at depth that lower photoinhibition in Prochlorococcus cells and/or presence of reef-specific metabolites that are re- 
leased as exudates from benthic organisms like corals and macroalgae. Concentrations of unpigmented cells (heterotrophic bacteria and archaea) in Micronesian waters were on average 438600 cells $\mathrm{ml}^{-1}$, which is about $30 \%$ of abundances measured on Cuban and Florida reefs (average 1600000 cells ml ${ }^{-1}$ ) (Weber et al. 2020), but are more in line with concentrations reported from the Line Islands as well as an embayment in Mo'orea (Dinsdale et al. 2008, Nelson et al. 2011). One possible explanation for these differences in unpigmented cell abundances is the high abundance of corals and filter feeders on the Micronesian/ Line Island/Mo'orea reefs, which may be ingesting these cells, thus driving down their abundances. Indeed, differential bacterioplankton abundances on the reefs of Mo'orea were attributed to this feeding hypothesis (Nelson et al. 2011). Additionally, a mesocosm-based experiment showed evidence for removal of specific bacteria from the microbial community over time, possibly due to predation by corals or coral-associated epibionts (McNally et al. 2017). These heterotrophic cell differences between the reefs may also be related to the differential benthic composition of Pacific and Caribbean reefs, which may affect the labile dissolved organic carbon (DOC) pool and heterotrophic cell growth (e.g. Nelson et al. 2013). On the Micronesian reefs, ratios of heterotrophic cells were relatively consistent except for Kosrae reefs, where ratios were much higher due to lower abundances of Prochlorococcus and Synechococcus. Kosrae reefs were also highest in coral coverage and diversity, and this removal of picocyanobacterial cells could be attributed to ingestion (McNally et al. 2017) or availability of labile DOC.

The amplicon sequencing data showed that the Micronesian reef microbial communities harbored consistently high alpha diversity. Similar methods were used on Floridian and Cuban reefs by Weber et al. (2020), thus providing an opportunity to directly compare findings. Microbial richness in Micronesia (340-425 MED nodes) was most similar to that of the Cuban Jardines de la Reina offshore reefs (320 MED nodes), and higher than coastal and nearshore reefs in Cuba and Florida (mean 140-280 MED nodes). This finding suggests that proximity to land, and therefore relationships to run-off of nutrients or pollutants, or tidal influences could be a factor contributing to decreased microbial diversity. We also identified significant relationships between coral and macroalgal coverage and number of MEDs associated with reef depth waters. These same relationships were not found when using Shannon and Simpson's alpha diversity indices, indicating that this trend is due to numbers of differential sequences, and does not account for community evenness. To our knowledge, this is the first study to report a statistical relationship between microbial species diversity and coral/macroalgal coverage on reefs, which is consistent with the finding that protected reefs harbor higher microbial diversity than less protected locations (Weber et al. 2020). Due to the similarities in the most abundant members of the microbial community between sites, this benthic community-based difference in microbial richness is most likely driven by community members belonging to rarer MED nodes (containing fewer sequences compared to the abundant community members). Indeed, we identified Leisingera, Owenweeksia, and Vibrio sequences enriched on the coral-abundant reefs as well as unclassified sequences belonging to the Flavobacteriaceae, OM27 clade, PB19 clade of Desulfuoromonadales, and the NS4 marine group. Marine isolates of Leisingera can grow on betaine (Vandecandelaere et al. 2008), which is produced by many corals (Hill et al. 2010). Owenweeksia and the OM27 clade are enriched in the near-coral seawater environment (Weber et al. 2019), and Vibrio are the most frequently recovered sequences from corals (Huggett \& Apprill 2019). Thus, corals and their metabolic products appear to be linked to the composition of the overlying reef-water microbial community.

Microbial communities throughout the Micronesian reefs were 65-85\% similar in composition and dominated by oligotrophic-dwelling microbial taxa, including Synechococcus, Prochlorococcus, SAR11 clades (I, Ia, Ib, and II), SAR86, SAR116, AEGEAN169, and 'Candidatus Actinomarina', among others. These communities are similar in composition to other reports from the Caribbean (Weber et al. 2020) and the Line Island and Polynesian reefs in the Pacific (Nelson et al. 2011, Kelly et al. 2014, Haas et al. 2016). However, the reef-water microbial taxa found in all of these prior studies, as well as this study, are also similar in SSU rRNA gene sequence taxonomy to taxa sampled in the surface waters of the open ocean (e.g. Brown et al. 2009, Giovannoni \& Vergin 2012). It is not yet clear how microbial taxa residing within coral reef habitats function in relation to their open ocean counterparts, and comparing genomes from these dominant cells recovered from open ocean and reef environments could help inform this question. Notably, surface water microbial community composition was related to ammonium and silicate concentrations, which may indicate their relationship or co-variation with these nutrients. Measurements from the only off-reef (open water) 
site suggest that the non-reef waters harbor relatively fewer sequences of Synechococcus and the Euryarchaeota family Thermosplasmatales, compared to the reef sites. Elevated growth and representation of Synechococcus in coastal environments compared to open ocean is well studied (Partensky et al. 1999), including in reef environments (Nelson et al. 2011). The elevated abundance of Thermoplasmatales in reef environments could be related to reef organisms (Kellogg 2004).

\subsection{Reef depth microbial community structure exhibits biogeographic patterns}

Planktonic marine microorganisms are thought to exhibit biogeographic patterns, which are driven by the local environmental conditions and historical events such as limitations in dispersal (reviewed by Martiny et al. 2006). Here we observed biogeographical partitioning in the microbial communities, suggested by the island/atoll-based differences in microbial community structure as well as correlation between reef depth seawater microbial community similarity and geographic distance. Biogeographical patterns in reef depth microorganisms were previously shown for the eastern Pacific, including the Hawaiian Archipelago, Johnston Atoll, and American Samoan reefs (Salerno et al. 2016). A surface-waterbased biogeographical study of Indian Ocean reefs crossed over distinct marine biogeographic provinces, and suggested that some of the observed reef biogeography was driven by primary production and thermohaline properties of the water (Jeffries et al. 2015). Interestingly, in our study we did not detect a correlation between surface reef-water microbial community structure and geographic distances, suggesting that currents may erode biogeographic patterns in surface waters. In contrast, the significant correlation between reef depth seawater microbial community similarity and geographic distance between reefs indicates that geographic or island-based factors observed in this study are more influential on microbial growth at reef depth. This may be due to more localized pulses of nutrients and physical dynamics contained within the reef benthic boundary layer at each reef (Shashar et al. 1996, Stocking et al. 2016). Microbial dispersal-based limitations could also play a role in these observed biogeographic patterns (Martiny et al. 2006, 2011), but, due to the shallow nature of these reefs, it seems unlikely that dispersion alone would cause the observed differences in surface and reef depth biogeography.

\subsection{Unique microbial community features in Kosrae may be linked to the dense and diverse coral communities}

There is a growing body of work examining the connections between benthic substrates on reefs and the overlying microbial ecology, and this study adds to that knowledge. Previous investigations have found linkages between the benthic flora and fauna on reefs and the pelagic microbial communities and their associated functional genes that overlie the reefs (Kelly et al. 2014, Haas et al. 2016, Weber et al. 2019, Glasl et al. 2020). Here we identified microbial and organic carbon and nitrogen features that are unique to the Kosrae reefs ( $\mathrm{n}=3$ sites), which harbored the most dense and diverse coral communities in our study. Indeed, concentrations of TOC at Kosrae reefs were the lowest measured in our study (59.8-67.9 $\mu \mathrm{M})$. In contrast, the concentrations of TOC measured on the macroalgal-dominated reef of Olimarao (mean $45 \%$ macroalgae cover) were considerably higher (on average) than Kosrae, ranging from 63.9 to $77.9 \mu \mathrm{M}$. Concentrations of organic nitrogen at Kosrae were among the highest in the study $(4.5-5.3 \mu \mathrm{M})$, indicating possible production of dissolved organic nitrogen such as by diazotrophs. We also observed elevated ratios of heterotrophic compared to autotrophic cells on Kosrae, compared to other Micronesian islands and atolls. Interestingly, our findings for Kosrae and Olimarao are not consistent with descriptions of 'microbialized' reefs, which suggests that algal-dominant reefs have lower standing stocks of DOC and higher abundances of heterotrophic microbial metabolisms compared to reefs with higher coral coverage (Haas et al. 2016). In contrast, we found a higher ratio of heterotrophs compared to autotrophs, potentially responsible for the low organic carbon concentrations, on reefs with low algal cover. Although the concentrations of organic carbon (DOC vs. TOC) are not directly comparable between the studies, our observations of enhanced organic carbon with increased macroalgal cover in this study suggest that there may be variation in the microbial response to benthic community composition, and additional replication across coral and macroalgal-sites in Micronesia are needed to further verify this trend.

The reef-water microbial community at Kosrae was also highly diverse (425 MED nodes), and more consistent between reef sites (85\% similar), compared to the other islands and atolls we measured in our study. These features may be related to the high coral abundance and diversity at these sites. Further, we identified a suite of microorganisms differentially 
enriched on these reefs (compared to those of the macroalgal-rich reefs of Olimarao), which are not typical of surface oligotrophic waters, including Marinobacterium, Owenweeksi, Cryomorphaceae, the PB19 group of Desulfuromondales, and SAR11 clade III. This comparison also showed that typical oligotrophic bacteria were also differentially enriched in both Kosrae and Olimarao reefs, and the drivers of these relationships are less clear. The 'coral ecosphere' was recently described as the near-coral reefwater environment that supports a unique microbial community compared to just $1 \mathrm{~m}$ off the reef, and growth of microorganisms in this coral ecosphere environment may be influenced by coral and reefproduced metabolites (Weber et al. 2019). Similarly, other studies show that exposure to coral and macroalgal exudates influence microbial community composition and growth (Nelson et al. 2013, Cárdenas et al. 2018). In fact, high growth rates of SAR11 cells (1.2 cells $\mathrm{d}^{-1}$ ) were observed experimentally in the presence of corals (McNally et al. 2017). Further investigation of the relationship between microbial diversity and growth and coral exudate quality and quantity is needed to better understand the factors contributing to microbial patterns associated with coral-abundant reefs.

There is interest in developing and using reefwater microbial communities, as well as other reefassociated parameters, as predictive indicators of reef health and water quality (Glasl et al. 2017, 2018). Further exploration of the relationship between microbial richness and benthic cover on globally distributed reefs could help us understand the utility of this metric for predicting reef health. Additionally, microorganisms can be useful indicators of reefs which require further study. For example, microbial abundance and microbial community features were unique at the Poh 2 and Nuk 1 sites, yet no other environmental factors measured in this study explained their distinct microbial communities. Overall, additional survey studies of geographically distinct reefs are needed to develop a microbial diagnostic indicator concept for reefs.

\subsection{Considerations}

This study is the first to report on the microbial ecology of Micronesian reefs and provides insights into how nutrient concentrations, benthic composition, and biogeographic features related to the microbial community. Additionally, we describe particularly unique microbial and organic matter-based features on Kosrae Island reefs, which may be attributed to the high coral abundance and diversity at these reefs. We expect that the benthic coverage and fish abundances of these reefs likely changed between when this study took place (2012) and the time of publication, due to the coral bleaching events that occurred between 2013 and 2017. During this time period, staghorn Acropora and other corals may have died, thus impacting coral coverage and diversity (Raymundo et al. 2019). As such, there is now an opportunity to return to these reefs and examine how the reef microbial biogeochemistry and ecology has changed during this period of potential bleaching in the coral communities, thus providing new insights for developing microbial communities as indicators of reef health.

Our study reported on limited geographic coverage throughout the islands and sampled across different types of reefs (lagoon, forereef, and fringing), which can influence reef-water microbial ecology (Apprill \& Rappé 2011, Nelson et al. 2011). Sampling of reef types was inconsistent between atolls and islands, and therefore did not allow for direct comparison between lagoon, forereef, and fringing reef microbial biogeochemistry. Future efforts could target sampling of these reef types per geographic region, to better constrain the factors contributing to variability between reefs. Additionally, our sampling scheme consisted of observations collected at a single point in time and do not cover seasonal trends (McCliment et al. 2012) or the diel or daily dynamics uncovered in recent reef studies (Kelly et al. 2014, Weber \& Apprill 2020). Nonetheless, this study offers new insights into the Micronesian reefs at an important time when understanding reef health and functioning is of critical importance to predicting the fate of and designing strategies to protect these essential ecosystems.

Acknowledgements. Samples were collected under Federated States of Micronesia collection permits FM12-11-03S and FM12-11-05S. This project was supported by funding to A.A.: Woods Hole Oceanographic Institution Access to the Sea, Dalio Family Foundation, Andrew W. Mellon Foundation Endowed Fund for Innovative Research, and National Science Foundation awards OCE- 1233612 and OCE-1736288. A.E.S. was supported by startup funds from the University of Maryland Center for Environmental Sciences. K.H. obtained funding from WHOI Access to the Sea and the Dalio Explore Foundation that supported this cruise. We thank the crew and captain of the MV 'Alucia' for their support with this project, as well as sampling assistance from Justin Ossolinski and Chad Smith (WHOI). Thanks to Joe Jennings at Oregon State University for inorganic nutrient analysis, Krista Longnecker at WHOI for organic carbon and total nitrogen analysis, Karen Selph at the University of Hawaii for flow cytometry analysis, 
Chris Wright and the University of Illinois W. M. Keck Center for Comparative and Functional Genomics for sequencing support, and Meg Maddox at the University of Maryland Center for Environmental Sciences for phytoplankton pigment analysis. Any use of trade, firm, or product names is for descriptive purposes only and does not imply endorsement by the US Government.

\section{LITERATURE CITED}

Abraham T, Berger M, Burdick D, Cochrane E and others (2004) Status of the coral reefs in Micronesia and American Samoa. In: Wilkinson C (ed) Status of Coral Reefs of the World: 2004, Vol 2. Australian Institute of Marine Science, Townsville, p 381-409

Anderson MJ (2001) A new method for non-parametric multivariate analysis of variance. Austral Ecol 26:32-46

Anderson MJ (2006) Distance-based tests for homogeneity of multivariate dispersions. Biometrics 62:245-253

Anderson MJ, Walsh DC (2013) PERMANOVA, ANOSIM, and the Mantel test in the face of heterogeneous dispersions: What null hypothesis are you testing? Ecol Monogr 83:557-574

Andrefouet S, Muller-Karger FE, Robinson JA, Kranenburg CJ, Torres-Pulliza D, Spraggins SA, Murch B (2006) Global assessment of modern coral reef extent and diversity for regional science and management applications: a view from space. Proc 10th Int Coral Reef Symp 2:1732-1745

Apprill A, Rappé MS (2011) Response of the microbial community to coral spawning in lagoon and reef flat environments of Hawaii, USA. Aquat Microb Ecol 62:251-266

Apprill A, McNally SP, Parsons R, Weber L (2015) Minor revision to $\mathrm{V} 4$ region SSU rRNA 806R gene primer greatly increases detection of SAR11 bacterioplankton. Aquat Microb Ecol 75:129-137

Armstrong FAJ, Stearns CR, Strickland JDH (1967) The measurement of upwelling and subsequent biological processes by means of the Technicon AutoAnalyzer and associated equipment. Deep-Sea Res Oceanogr Abstr 14:381-389

Bernhardt H, Wilhelms A (1967) The continuous determination of low-level iron, soluble phosphate and total phosphate with the Autoanalyzer. In: Technicon Symposia, Book 1. Automation in analytical chemistry. Mediad, New York, NY, p 385-389

Bray JR, Curtis JT (1957) An ordination of the upland forest communities of southern Wisconsin. Ecol Monogr 27: 325-349

Brown MV, Philip GK, Bunge JA, Smith MC and others (2009) Microbial community structure in the North Pacific ocean. ISME J 3:1374-1386

Caporaso JG, Lauber CL, Walters WA, Berg-Lyons D and others (2011) Global patterns of 16S rRNA diversity at a depth of millions of sequences per sample. Proc Natl Acad Sci USA 108(Suppl 1):4516-4522

Cárdenas A, Neave MJ, Haroon MF, Pogoreutz C and others (2018) Excess labile carbon promotes the expression of virulence factors in coral reef bacterioplankton. ISME J 12:59-76

Clarke KR, Warwick RM (2001) Change in marine communities: an approach to statistical analysis and interpretation, 2nd edn. PRIMER-E, Plymouth

Ne'ath G, Fabricius KE, Sweatman H, Puotinen M (2012) The 27-year decline of coral cover on the Great Barrier Reef and its causes. Proc Natl Acad Sci USA 109:17995-17999
Dinsdale EA, Pantos O, Smriga S, Edwards RA and others (2008) Microbial ecology of four coral atolls in the Northern Line Islands. PLOS ONE 3:e1584

Ducklow HW (1990) The biomass, production and fate of bacteria in coral reefs. In: Dubinsky Z (ed) Ecosystems of the World 25: coral reefs. Elsevier Science Publishing, Amsterdam, p 265-289

Edgar RC, Haas BJ, Clemente JC, Quince C, Knight R (2011) UCHIME improves sensitivity and speed of chimera detection. Bioinformatics 27:2194-2200

Eren AM, Morrison HG, Lescault PJ, Reveillaud J, Vineis JH, Sogin ML (2015) Minimum entropy decomposition: unsupervised oligotyping for sensitive partitioning of highthroughput marker gene sequences. ISME J 9:968-979

FSM National Government (2002) 2000 population and housing census report. Department of Economic Affairs, Palikir, Pohnpei. www.spc.int/DigitalLibrary/Doc/SDD/ Census/FM/FSM_2000_National_Census_Report.pdf

Gardner TA, Côté IM, Gill JA, Grant A, Watkinson AR (2003) Long-term region-wide declines in Caribbean corals. Science 301:958-960

* Giovannoni SJ, Vergin KL (2012) Seasonality in ocean microbial communities. Science 335:671-676

KGlasl B, Webster NS, Bourne DG (2017) Microbial indicators as a diagnostic tool for assessing water quality and climate stress in coral reef ecosystems. Mar Biol 164:91

* Glasl B, Bourne DG, Frade PR, Webster NS (2018) Establishing microbial baselines to identify indicators of coral reef health. Microbiol Aust 39:42-46

Glasl B, Bourne DG, Frade PR, Thomas T, Schaffelke B, Webster NS (2019) Microbial indicators of environmental perturbations in coral reef ecosystems. Microbiome 7:94

*Glasl B, Robbins S, Frade PR, Marangon E, Laffy PW, Bourne DG, Webster NS (2020) Comparative genomecentric analysis reveals seasonal variation in the function of coral reef microbiomes. ISME J 14:1435-1450

Goldberg J, Adams K, Albert J, Asher J and others (2008) Status of coral reef resources in Micronesia and American Samoa: 2008. In: Wilkinson C (ed) Status of Coral Reefs of the World: 2008. Global Coral Reef Monitoring Network and Reef and Rainforest Research Centre, Townsville, p 199-212

*Haas AF, Nelson CE, Rohwer F, Wegley-Kelly L and others (2013) Influence of coral and algal exudates on microbially mediated reef metabolism. PeerJ 1:e108

*Haas AF, Fairoz MFM, Kelly LW, Nelson CE and others (2016) Global microbialization of coral reefs. Nat Microbiol 1:16042

Hansell DA, Carlson CA (2001) Biogeochemistry of total organic carbon and nitrogen in the Sargasso Sea: control by convective overturn. Deep Sea Res II 48:1649-1667

Hill R, Li C, Jones A, Gunn J, Frade P (2010) Abundant betaines in reef-building corals and ecological indicators of a photoprotective role. Coral Reefs 29:869-880

* Holmes RM, Aminot A, Kerouel R, Hooker BA, Peterson BJ (1999) A simple and precise method for measuring ammonium in marine and freshwater ecosystems. Can J Fish Aquat Sci 56:1801-1808

* Houk P, Rhodes K, Cuetos-Bueno J, Lindfield S, Fread V, Mcllwain J (2012) Commercial coral-reef fisheries across Micronesia: a need for improving management. Coral Reefs 31:13-26

* Houlbrèque F, Tambutté E, Richard C, Ferrier-Pagès C (2004) Importance of a micro-diet for scleractinian corals. Mar Ecol Prog Ser 282:151-160 
Huggett MJ, Apprill A (2019) Coral microbiome database: Integration of sequences reveals high diversity and specificity of coral-associated microbes. Environ Microbiol Rep 11:372-385

Hughes TP, Kerry JT, Álvarez-Noriega M, Álvarez-Romero JG and others (2017) Global warming and recurrent mass bleaching of corals. Nature 543:373-377

Hughes TP, Kerry JT, Baird AH, Connolly SR and others (2018) Global warming transforms coral reef assemblages. Nature 556:492-496

Jeffries TC, Ostrowski M, Williams RB, Xie C and others (2015) Spatially extensive microbial biogeography of the Indian Ocean provides insights into the unique community structure of a pristine coral atoll. Sci Rep 5:15383

Kellogg CA (2004) Tropical Archaea: diversity associated with the surface microlayer of corals. Mar Ecol Prog Ser 273:81-88

Kelly LW, Williams GJ, Barott KL, Carlson CA and others (2014) Local genomic adaptation of coral reef-associated microbiomes to gradients of natural variability and anthropogenic stressors. Proc Natl Acad Sci USA 111: 10227-10232

Kozich JJ, Westcott SL, Baxter NT, Highlander S, Schloss PD (2013) Development of a dual-index sequencing strategy and curation pipeline for analyzing amplicon sequence data on the MiSeq Illumina sequencing platform. Appl Environ Microbiol 79:5112-5120

Martin BD, Witten D, Willis AD (2020) Modeling microbial abundances and dysbiosis with beta-binomial regression. Ann Appl Stat 14:94-115

Martiny JBH, Bohannan BJM, Brown JH, Colwell RK and others (2006) Microbial biogeography: putting microorganisms on the map. Nat Rev Microbiol 4:102-112

Martiny JB, Eisen JA, Penn K, Allison SD, Horner-Devine MC (2011) Drivers of bacterial $\beta$-diversity depend on spatial scale. Proc Natl Acad Sci USA 108:7850-7854

McCliment EA, Nelson CE, Carlson CA, Alldredge AL, Witting J, Amaral-Zettler LA (2012) An all-taxon microbial inventory of the Moorea coral reef ecosystem. ISME J 6: 309-319

McMurdie PJ, Holmes S (2014) Waste not, want not: why rarefying microbiome data is inadmissible. PLOS Comput Biol 10:e1003531

McNally S, Parsons R, Santoro A, Apprill A (2017) Multifaceted impacts of the stony coral Porites astreoides on picoplankton abundance and community composition. Limnol Oceanogr 62:217-234

Moberg F, Folke C (1999) Ecological goods and services of coral reef ecosystems. Ecol Econ 29:215-233

* Mumby P, Bejarano S, Golbuu Y, Steneck R, Arnold S, Van Woesik R, Friedlander A (2013) Empirical relationships among resilience indicators on Micronesian reefs. Coral Reefs 32:213-226

Muscatine L (1990) The role of symbiotic algae in carbon and energy flux in reef corals. In: Dubinsky Z (ed) Ecosystems of the World, Vol 25. Coral reefs. Elsevier Science Publishing Company, Amsterdam, p 75-87

Nelson CE, Alldredge AL, McCliment EA, Amaral-Zettler LA, Carlson CA (2011) Depleted dissolved organic carbon and distinct bacterial communities in the water column of a rapid-flushing coral reef ecosystem. ISME J 5: 1374-1387

Nelson CE, Goldberg SJ, Wegley Kelly L, Haas AF, Smith JE, Rohwer F, Carlson CA (2013) Coral and macroalgal exudates vary in neutral sugar composition and differen- tially enrich reef bacterioplankton lineages. ISME J 7: 962-979

*PPandolfi JM, Bradbury RH, Sala E, Hughes TP and others (2003) Global trajectories of the long-term decline of coral reef ecosystems. Science 301:955-958

*Parada AE, Needham DM, Fuhrman JA (2016) Every base matters: assessing small subunit rRNA primers for marine microbiomes with mock communities, time-series and global field samples. Environ Microbiol 18:1403-1414

Partensky F, Blanchot J, Vaulot D (1999) Differential distribution and ecology of Prochlorococcus and Synechococcus in oceanic waters: a review. Bull Inst Oceanogr NS19:457-475

* Quast C, Pruesse E, Yilmaz P, Gerken J and others (2013) The SILVA ribosomal RNA gene database project: improved data processing and web-based tools. Nucleic Acids Res 41:D590-D596

Raymundo LJ, Burdick D, Hoot WC, Miller RM and others (2019) Successive bleaching events cause mass coral mortality in Guam, Micronesia. Coral Reefs 38: $677-700$

* Rhodes KL, Warren-Rhodes KA, Sweet S, Helgenberger M, Joseph E, Boyle LN, Hopkins KD (2015) Marine ecological footprint indicates unsustainability of the Pohnpei (Micronesia) coral reef fishery. Environ Conserv 42: 182-190

* Richards Z (2015) The status of hard coral communities at Kosrae, Micronesia. Mar Biodivers 45:655-666

* Salerno JL, Bowen BW, Rappé MS (2016) Biogeography of planktonic and coral-associated microorganisms across the Hawaiian Archipelago. FEMS Microbiol Ecol 92:fiw109

* Sandin SA, Smith JE, DeMartini EE, Dinsdale EA and others (2008) Baselines and degradation of coral reefs in the Northern Line Islands. PLOS ONE 3:e1548

* Santoro AE, Casciotti KL, Francis CA (2010) Activity, abundance and diversity of nitrifying archaea and bacteria in the central California Current. Environ Microbiol 12: 1989-2006

* Schloss PD, Westcott SL, Ryabin T, Hall JR and others (2009) Introducing mothur: open-source, platform-independent, community-supported software for describing and comparing microbial communities. Appl Environ Microbiol 75:7537-7541

Shashar N, Kinane S, Jokiel P, Patterson M (1996) Hydromechanical boundary layers over a coral reef. J Exp Mar Biol Ecol 199:17-28

Sorokin YI (1973a) Microbiological aspects of the productivity of coral reefs. Biol Geol Coral Reefs 2:17-45

Sorokin YI (1973b) Trophical role of bacteria in the ecosystem of the coral reef. Nature 242:415-417

* Stocking JB, Rippe JP, Reidenbach MA (2016) Structure and dynamics of turbulent boundary layer flow over healthy and algae-covered corals. Coral Reefs 35:1047-1059

Taylor BW, Keep CF, Hall RO, Koch BJ, Tronstad LM, Flecker AS, Ulseth AJ (2007) Improving the fluorometric ammonium method: matrix effects, background fluorescence, and standard additions. J N Am Benthol Soc 26: $167-177$

US Environmental Protection Agency (1983) Methods for chemical analysis of water and wastes, Book EPA-600/ 479-020. EPA, Cincinnati, OH

Vandecandelaere I, Segaert E, Mollica A, Faimali M, Vandamme P (2008) Leisingera aquimarina sp. nov., isolated from a marine electroactive biofilm, and emended descriptions of Leisingera methylohalidivorans Schaefer et al. 
2002, Phaeobacter daeponensis Yoon et al. 2007 and Phaeobacter inhibens Martens et al. 2006. Int J Syst Evol Microbiol 58:2788-2793

Weber L, Apprill A (2020) Diel, daily, and spatial variation of coral reef seawater microbial communities. PLOS ONE 15:e0229442

Weber L, Gonzalez-Díaz P, Armenteros M, Apprill A (2019) The coral ecosphere: a unique coral reef microbial habitat that fosters coral-microbial interactions. Limnol Oceanogr 64:2373-2388

Weber L, González-Díaz P, Armenteros M, Ferrer VM and others (2020) Microbial signatures of protected and

Editorial responsibility: Fereidoun Rassoulzadegan,

Villefranche-sur-Mer, France

Reviewed by: 2 anonymous referees impacted Northern Caribbean reefs: changes from Cuba to the Florida Keys. Environ Microbiol 22:499-519

W.Weiss S, Xu ZZ, Peddada S, Amir A and others (2017) Normalization and microbial differential abundance strategies depend upon data characteristics. Microbiome 5:27

WWilkinson CR (1983) Net primary productivity in coral reef sponges. Science 219:410-412

*Wilkinson C, Fay P (1979) Nitrogen fixation in coral reef sponges with symbiotic cyanobacteria. Nature 279:527-529

* Yeo SK, Huggett MJ, Eiler A, Rappé MS (2013) Coastal bacterioplankton community dynamics in response to a natural disturbance. PLOS ONE 8:e56207

Submitted: June 8, 2020

Accepted: January 12, 2021

Proofs received from author(s): April 9, 2021 